\title{
Extracardiac Complications in Intensive Care Units after Surgical Repair for Congenital Heart Disease: Imaging Review with a Focus on Ultrasound and Radiography
}

\author{
Takahiro Hosokawa $^{1}$ Saki Shibuki ${ }^{1}$ Yutaka Tanami ${ }^{1}$ Yumiko Sato ${ }^{1}$ Yoshihiro Ko ${ }^{2}$ Koji Nomura ${ }^{2}$ \\ Eiji Oguma ${ }^{1}$
}
${ }^{1}$ Department of Radiology, Saitama Children's Medical Center, Saitama, Japan
2 Department of Cardiovascular Surgery, Saitama Children's Medical Center, Saitama, Japan

J Pediatr Intensive Care 2021;10:85-105. Address for correspondence Takahiro Hosokawa, MD, Department of
Radiology, Saitama Children's Medical Center, 1-2 Shintoshin Chuo-ku
Saitama, Saitama 330-8777, Japan (e-mail: snowglobe@infoseek.jp).

\author{
Abstract \\ Keywords \\ - complication \\ - pediatric \\ - cardiovascular \\ surgery
}

Pediatric patients show various extracardiac complications after cardiovascular surgery, and radiography and ultrasound are routinely performed in the intensive care unit to detect and evaluate these complications. This review presents images of these complications, sonographic approach, and timing of occurrence that are categorized based on their extracardiac locations and include complications pertaining to the central nervous system, mediastinum, thorax and lung parenchyma, diaphragm, liver and biliary system, and kidney along with pleural effusion and iatrogenic complications. This pictorial review will make it easier for medical doctors in intensive care units to identify and manage various extracardiac complications in pediatric patients after cardiovascular surgery.

\section{Introduction}

Various extracardiac complications have been reported in pediatric patients after cardiovascular surgery. ${ }^{1}$ These patients should receive early and appropriate interventions to prevent a prolonged stay in the intensive care unit. ${ }^{2-4}$ Radiography and ultrasound are routinely performed at patients' bedside by pediatric physicians, cardiologists, intensivists, or radiologists to detect these complications and evaluate the patients' condition while they are admitted to the intensive care unit. ${ }^{3,5-7}$

To the best of our knowledge, although some previous reports have focused on the risk factors for the occurrence of these complications and their prognosis, there are no reports focusing on the image findings of these complications. The purpose of this review is to show the image findings of these complications using radiography and ultrasound..$^{2,8-10}$ This pictorial review will help doctors in intensive care units to more easily identify and manage various extracardiac complications in pediatric patients after cardiovascular surgery.

\section{Classification Based on the Location of the Extracardiac Organ}

The extracardiac complications occurring after cardiovascular surgery are classified based on the locations of occurrence. - Tables 1 and $\mathbf{2}$ show locations and types of these complications ( - Table 1: locations and types of complications and intrathoracic and diaphragmatic complications, and - Table 2: locations and types of complications and intra-abdominal and other locations' complications). Although their incidence and timing of onset vary depending on the underlying congenital received

June 3,2020

accepted

June 24, 2020

published online

September 9, 2020 (c) 2020. Thieme. All rights reserved.

Georg Thieme Verlag KG,

Rüdigerstraße 14,

70469 Stuttgart, Germany
DOI https://doi.org/ 10.1055/s-0040-1715483. ISSN $2146-4618$. 
Table 1 Locations and types of complications: intrathoracic and diaphragmatic complications

\begin{tabular}{|c|c|c|c|c|c|}
\hline Location & Types & $\begin{array}{l}\text { Incidence (number } \\
\text { of occurrence/total } \\
\text { number) }\end{array}$ & $\begin{array}{l}\text { Interval between } \\
\text { surgery and diagnosis } \\
\text { average } \pm \text { SD (range) }\end{array}$ & Comments & Ref. \\
\hline \multirow[t]{16}{*}{ Mediastinum } & \multirow{5}{*}{$\begin{array}{l}\text { Hemorrhage/ } \\
\text { hematoma }\end{array}$} & $10 \%(6 / 54)$ & & & 115 \\
\hline & & $\mathrm{N} / \mathrm{A}$ & $16(12-22)$ days & 3 cases & 9 \\
\hline & & $4.1 \%(5 / 121)$ & & $\begin{array}{l}\text { Only patients who underwent } \\
\text { mechanical aortic valve } \\
\text { replacement were included }\end{array}$ & 116 \\
\hline & & $\mathrm{N} / \mathrm{A}$ & 1 and 10 days & 2 cases & 12 \\
\hline & & $11-40 \%$ & & $\begin{array}{l}\text { Variable bleeding rate depending on the } \\
\text { implanted durable devices }\end{array}$ & 117 \\
\hline & \multirow[t]{5}{*}{ SSI } & $\begin{array}{l}2.2 \%(9 / 412) \\
5.8 \%(24 / 412)\end{array}$ & & $\begin{array}{l}\text { Organ/space infection } \\
\text { DIl or SWI }\end{array}$ & 2 \\
\hline & & $\begin{array}{l}2.4 \%(27 / 1,117) \\
0.1 \%(1 / 1,117) \\
0.9 \%(10 / 1,117)\end{array}$ & & $\begin{array}{l}\text { Organ/space infection } \\
\text { DII } \\
\text { SWI }\end{array}$ & 118 \\
\hline & & $\begin{array}{l}0.8 \%(7 / 826) \\
1.5 \%(12 / 826)\end{array}$ & & $\begin{array}{l}\text { Organ/space infection } \\
\text { DIl and SWI }\end{array}$ & 119 \\
\hline & & $\mathrm{N} / \mathrm{A}$ & $\begin{array}{l}17.2(6-30) \text { days } \\
5 \text { and } 10 \text { days }\end{array}$ & $\begin{array}{l}6 \text { cases with DII and SWI } \\
2 \text { cases with organ/space infection }\end{array}$ & 120 \\
\hline & & $\begin{array}{l}6.3 \%(384 / 6,127) \\
1.8 \%(107 / 6,127)\end{array}$ & & $\begin{array}{l}\text { Wound infection with delayed sternal } \\
\text { closure } \\
\text { Mediastinitis with delayed sternal closure }\end{array}$ & 121 \\
\hline & \multirow{6}{*}{$\begin{array}{l}\text { Mediastinitis } \\
\text { (organ/space } \\
\text { infection) }\end{array}$} & $1.1 \%(29 / 2,675)$ & $10(5-27)$ days & & 122 \\
\hline & & $\mathrm{N} / \mathrm{A}$ & $27.3(7-53)$ days & & 9 \\
\hline & & $0.2 \%(17 / 7,616)$ & 14 (6-50 days) days & & 18 \\
\hline & & $0.85 \%(57 / 6,705)$ & 13 days & & 123 \\
\hline & & $1.7 \%(64 / 3,650)$ & $13.4(4-37)$ days & & 126 \\
\hline & & $8.3 \%(3 / 36)$ & $8.8(5-14)$ days & $\begin{array}{l}\text { Only neonate (under } 4 \text { weeks of age) } \\
\text { were included }\end{array}$ & 127 \\
\hline \multirow[t]{4}{*}{ Pleural effusion } & Pleural effusion & $\mathrm{N} / \mathrm{A}$ & & & \\
\hline & Hemothorax & $\mathrm{N} / \mathrm{A}$ & & & \\
\hline & Chylothorax & $5 \%(57 / 1,135)$ & $0-10$ days & & 23 \\
\hline & & $5 \%(12 / 238)$ & & $\begin{array}{l}\text { Chylothorax or plastic bronchitis. All } \\
\text { cases with Fontan procedure were } \\
\text { included. }\end{array}$ & 30 \\
\hline Thorax & Pneumothorax & $N / A$ & & & \\
\hline Lug parenchyma & Atelectasis & $\mathrm{N} / \mathrm{A}$ & & & \\
\hline Lung infection & $\begin{array}{l}\text { Pneumonia } \\
\text { Respiratory } \\
\text { infection upper } \\
\text { Respiratory } \\
\text { infection lower }\end{array}$ & $\begin{array}{l}0.7 \%(3 / 412) \\
1.7 \%(7 / 412) \\
0.5 \%(2 / 412)\end{array}$ & & & 2 \\
\hline \multirow[t]{4}{*}{ Diaphragm } & \multirow[t]{4}{*}{$\begin{array}{l}\text { Diaphragmatic } \\
\text { paralysis }\end{array}$} & $1.5 \%(25 / 1,656)$ & & $\begin{array}{l}\text { Plication rate was } 44 \% \text {, and the procedure } \\
\text { was performed } 2-3 \text { weeks after operation }\end{array}$ & 128 \\
\hline & & $0.46 \%(47 / 10,200)$ & & $\begin{array}{l}\text { Plication rate was } 79 \% \text {, and the } \\
\text { procedure was performed } 24 \pm 14 \text { days } \\
\text { after the operation }\end{array}$ & 41 \\
\hline & & $2.1 \%(19 / 891)$ & & Plication rate was $79 \%$ & 40 \\
\hline & & $4.9 \%(152 / 3,071)$ & & $\begin{array}{l}\text { Plication rate was } 1.3 \% \text {, and the } \\
\text { procedure was performed } 17.8 \pm 3.6 \\
\text { days after the operation }\end{array}$ & 39 \\
\hline
\end{tabular}

Abbreviations: DII, deep incisional infection; N/A, not available; Ref., reference; SD, standard deviation; SSI, surgical site infection; SWI, superficial wound infection. 
Table 2 Locations and types of complications: intra-abdominal and other locations' complications

\begin{tabular}{|c|c|c|c|c|c|}
\hline Location & Types & $\begin{array}{l}\text { Incidence (number } \\
\text { of occurrence/ } \\
\text { total number) }\end{array}$ & $\begin{array}{l}\text { Interval between } \\
\text { surgery and diagnosis } \\
\text { average } \pm S D \text { (range) }\end{array}$ & Comments & Ref. \\
\hline \multirow[t]{3}{*}{ CNS } & $\begin{array}{l}\text { IVH } \\
\text { Cerebral infarction }\end{array}$ & $\begin{array}{l}0.9 \%(5 / 543) \\
1.7 \%(9 / 543)\end{array}$ & & & 49 \\
\hline & $\mathrm{IVH}$ & $17 \%(6 / 34)$ & $\begin{array}{l}4 \text { hours after the } \\
\text { surgery (routine } \\
\text { examination) }\end{array}$ & Arterial switch operation in neonates & 50 \\
\hline & Subdural hemorrhage & $0.1 \%(1 / 706)$ & & & 47 \\
\hline \multirow[t]{2}{*}{$\begin{array}{l}\text { Liver and } \\
\text { biliary } \\
\text { system }\end{array}$} & $\begin{array}{l}\text { Acute liver failure } \\
\text { (liver insufficiency) }\end{array}$ & $15 \%(8 / 54)$ & & $\begin{array}{l}\text { This study focused on the NEC. } \\
\text { Neonates with and without NEC were } \\
\text { included. }\end{array}$ & 70 \\
\hline & $\begin{array}{l}\text { Debris within biliary } \\
\text { system }\end{array}$ & $\mathrm{N} / \mathrm{A}$ & 19th day & Case report & 130 \\
\hline \multirow[t]{10}{*}{ Intestine } & \multirow[t]{4}{*}{ NEC } & $11 \%(8 / 73)$ & & & 70 \\
\hline & & $18 \%(9 / 43)$ & & Hypoplastic left heart syndrome & 68 \\
\hline & & $\begin{array}{l}13 \%(14 / 108) \\
12 \%(8 / 66) \\
14 \%(7 / 50)\end{array}$ & $\begin{array}{l}25 \pm 17 \text { (days of life) } \\
36 \pm 19 \text { (days of life) } \\
22 \pm 15 \text { (days of life) }\end{array}$ & $\begin{array}{l}\text { Indomethacin (performed } 4 \pm 3 \text { days of life) } \\
\text { Indomethacin and ligation ( } 11 \pm 8 \text { days of life) } \\
\text { Ligation ( } 9 \pm 13 \text { days of life) } \\
\text { Treatment for PDA in premature neonates; }\end{array}$ & 73 \\
\hline & & $\begin{array}{l}11.0 \%(8 / 65) \\
5.8 \%(3 / 49)\end{array}$ & & $\begin{array}{l}\text { Only neonates performed the Norwood } \\
\text { procedure were included and using different } \\
\text { protocol of enteral feeding }\end{array}$ & 131 \\
\hline & & $\begin{array}{l}14 / 52(27 \%) \\
3 / 46(6.5 \%)\end{array}$ & & $\begin{array}{l}\text { Hypoplastic left heart syndrome after the } \\
\text { Norwood procedure and using different } \\
\text { protocol of enteral feeding }\end{array}$ & 71 \\
\hline & & $\mathrm{N} / \mathrm{A}$ & $\begin{array}{l}21 \text { postoperative hours } \\
\text { (1 case) } \\
1 \text { postoperative day ( } 2 \\
\text { cases) }\end{array}$ & 3 cases reports & 69 \\
\hline & & $1.7 \%(19 / 1120)$ & & & 67 \\
\hline & \multirow{2}{*}{$\begin{array}{l}\text { Paradoxical } \\
\text { hypertension result in } \\
\text { postcoarctectomy } \\
\text { syndrome or } \\
\text { mesenteric arteritis }\end{array}$} & $56 \%(14 / 25)$ & & After repair of coarctation of the aorta & 86 \\
\hline & & $6 \%(9 / 145)$ & $4(3-6)$ days & After repair of coarctation of the aorta & 72 \\
\hline & Gastroenteritis & $0.08 \%(1 / 1120)$ & & & 67 \\
\hline \multirow[t]{8}{*}{ Kidney } & \multirow[t]{7}{*}{ AKI } & $90 \%(53 / 59)$ & & Using ECMO during cardiovascular surgery & 132 \\
\hline & & $54 \%(352 / 613)$ & $2(1-6)$ days & $\begin{array}{l}\text { AKI remained stable until 4th postoperative } \\
\text { days }\end{array}$ & 133 \\
\hline & & $62 \%(76 / 122)$ & $\begin{array}{l}\text { Progression of AKI } \\
\text { within } 48 \text { hours after } \\
\text { surgery }\end{array}$ & Only neonates were included & 8 \\
\hline & & $35 \%(33 / 125)$ & $\begin{array}{l}1 \text { postoperative day in } \\
57 \% \text { of cases ( } 1-27 \text { days) }\end{array}$ & $\begin{array}{l}\text { Most cases resolved within } 24 \text { hours (65\% of } \\
\text { cases) }\end{array}$ & 94 \\
\hline & & $\begin{array}{l}26 \%(51 / 194) \\
14 \%(28 / 201)\end{array}$ & & $\begin{array}{l}<2 \text { years } \\
\geq 2 \text { years }\end{array}$ & 134 \\
\hline & & $17 \%(53 / 311)$ & $\begin{array}{l}\text { Sever AKI (receipt of } \\
\text { acute dialysis) }\end{array}$ & & 137 \\
\hline & & $51 \%(234 / 458)$ & $\begin{array}{l}\text { Usually within } 48 \text { hours } \\
\text { after surgery }\end{array}$ & & 135 \\
\hline & UTI & $3.6 \%(15 / 412)$ & & & 2 \\
\hline \multirow{3}{*}{$\begin{array}{l}\text { Vascular } \\
\text { complica- } \\
\text { tion }^{\mathrm{a}}\end{array}$} & $\begin{array}{l}\text { Phlebitis associated } \\
\text { PICC }^{\text {a }}\end{array}$ & $13 \%(83 / 654)$ & $\begin{array}{l}86 \text { hours ( } 12-286 \text { hours } \\
\text { after insertion) }\end{array}$ & & 105 \\
\hline & $\begin{array}{l}\text { Venous } \\
\text { thromboembolism }\end{array}$ & $2 \%(65 / 2,718)$ & & & 136 \\
\hline & Thrombosis & $\begin{array}{l}15 \%(8 / 53) \\
16 \%(6 / 37)\end{array}$ & $\begin{array}{l}4.8 \pm 3.7 \text { days } \\
5.1 \pm 3.6 \text { days }\end{array}$ & $\begin{array}{l}\text { With heparin } \\
\text { With placebo }\end{array}$ & 106 \\
\hline
\end{tabular}

Abbreviations: AKI, acute kidney injury; CNS, central nervous system; ECMO, extracorporeal membrane oxygenation; IVH; Intraventricular hemorrhage; N/A, not available; NEC, necrotizing enterocolitis; PDA, patent ductus arteriosus; PICC, peripheral inserted central catheter; SD, standard deviation; UTI, urinary tract infection.

${ }^{a}$ Catheter-associated complications: there were no previous reports focusing on pediatric patients after cardiovascular surgery; therefore, these incidences were reported from studies targeting pediatric patients. 
heart diseases, treatments or institutions' comprehensive data pertaining to these complications are important for daily management and evaluation of pediatric patients after cardiovascular surgery in the intensive care unit.

\section{Approach Methods Using Ultrasound for Various Complications}

In clinical settings, abdominal or cardiac ultrasound is usually performed, whereas in intensive care units, ultrasound is performed for various sites (-Fig. 1). The approach for nonfamiliar sites may differ across physicians; therefore, a schematic guideline to demonstrate the approach methods for nonfamiliar target organs, such as the cranium, trachea, mediastinum, lungs, and diaphragm, is necessary. ${ }^{3,11-15}$ Vascular complications can be found at any location; hence, point-of-care ultrasound is useful.

\section{Timing of Examination}

In the guideline for after surgical repair for congenital heart disease, if a change in clinical status or new concerning signs or symptoms are detected, computed tomography (CT) and radiography could be recommended. ${ }^{16}$ In the guideline, however, transesophageal echocardiogram is included but ultrasound targeting the abdomen or other organs is not included. ${ }^{16}$ The timing of examination could be varied based on the kinds of complication and of modality used for the diagnosis. Therefore, the timing of occurrence of each complication and strategy, including the modality for diagnosing the complications, was stated in each below section of complications.

\section{Locations and Types of Complications: Intrathoracic and Diaphragmatic Complications}

\section{Mediastinum}

Information regarding mediastinal complications, including surgical site infection (mediastinitis) and hemorrhage, is important to ensure appropriate intervention ( $\mathbf{- T a b l e ~} \mathbf{1}$ ).

\section{Timing of Occurrence and Strategy for the Diagnosis}

The complications in the mediastinum include hemorrhage or surgical site infection. Mediastinal hemorrhage usually occurs within 1 week after intrathoracic surgery. ${ }^{9,17-19}$ The surgical site infection (organ/space infection [mediastinitis]) usually occurs 1 week after intrathoracic surgery. ${ }^{9,17-19}$ Computed tomography is reported to be a useful modality for diagnosing mediastinitis; however, this modality requires radiation exposure and cannot be performed at a patient's bedside; ultrasound

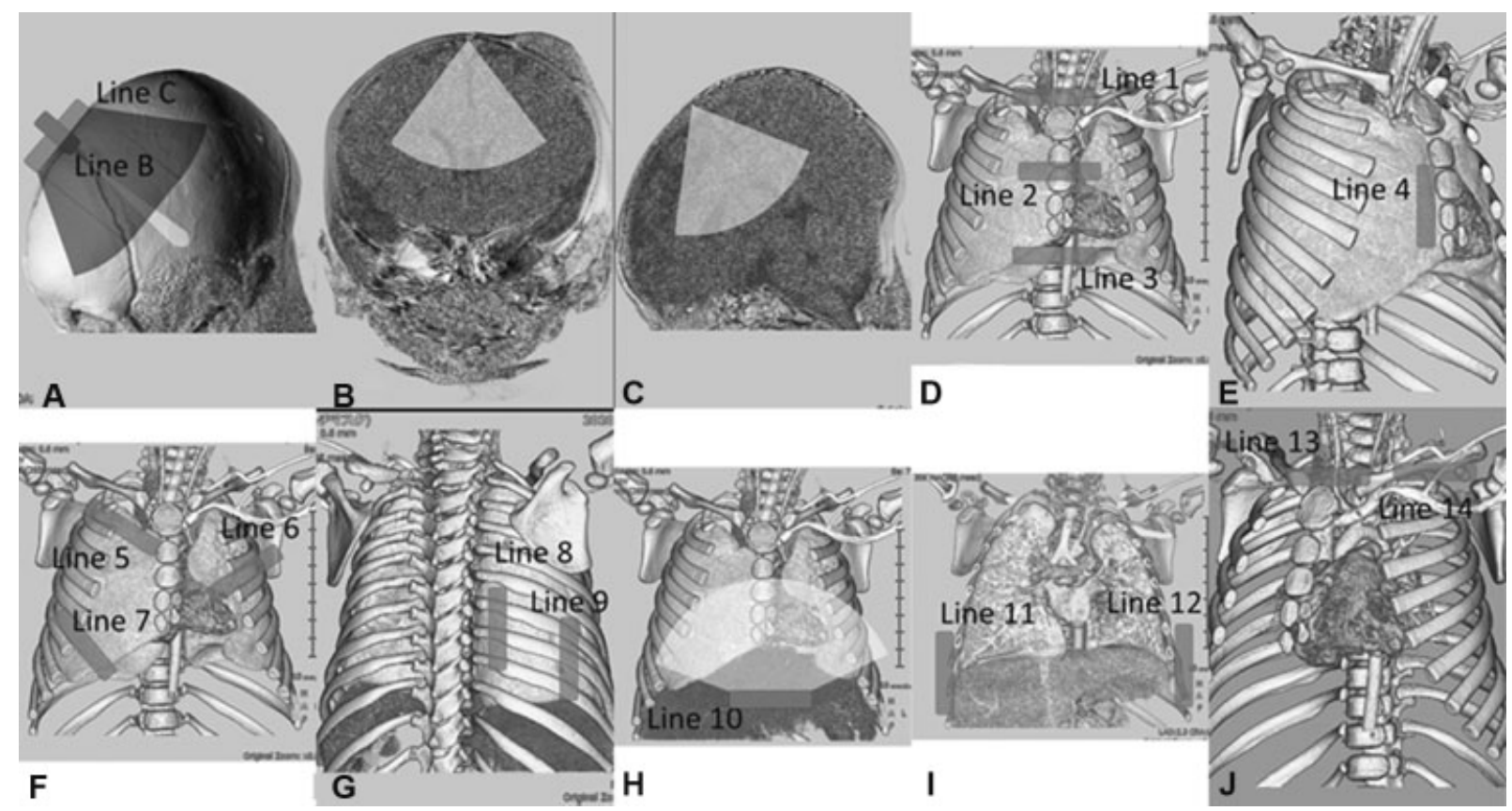

Fig. 1 Schematic presentation of the standard scanning approach. (A) Correct placement of the transducer for cranial approach via posterior fontanelle to obtain the coronal or sagittal view. (B) Schematic presentation of coronal view via the posterior fontanelle. Transducer is located at the line $B$ in $\boldsymbol{- F i g . 1 A}$ ( $\sim$ Fig 2A). (C) Schematic presentation of sagittal view via the posterior fontanelle. Transducer is located at the line $C$ in the - Fig. 1A ( - Fig 2B). (D) Tracheal tube evaluation using axial view at above the suprasternal approach (line 1) ( evaluation using axial view at the suprasternal (line 1), transsternal (line 2), or subxiphoid approach (line 3). (E) Mediastinum evaluation using sagittal view at the parasternal approach (line 4) (-Figs. 3-5). (F) Lung evaluation by using ultrasound. Intercostal or parasternal approach is used. Each thorax is divided into some areas and almost the entire area of the lung can be evaluated (upper lung, line 5; middle lung, line 6; base lung, line 7 (-Fig. 12B and 12D). (G) Posterior paraspinal approach is useful for to the posterior lung parenchyma (medial side, line 8; lateral side, line 9). (H) Diaphragmatic motion of both right- and left-side evaluation using axial view at the subxiphoid (line 10). Movement of the mediastinum can be also evaluated (-Fig 13D). (I) Diaphragmatic motion evaluation using longitudinal view at the posterior axially line on each side (line 11 [ - Fig 13B] and 12 [ - Fig 13C]). (J) Vascular complications are evaluated in the affected vessel. Innominate vein is visualized using the at suprasternal approach (line 13; - Fig 23B). The subclavian vein and proximal side of the common carotid vein are visualized at the supraclavicular approach (line 14; - Fig 23A). 


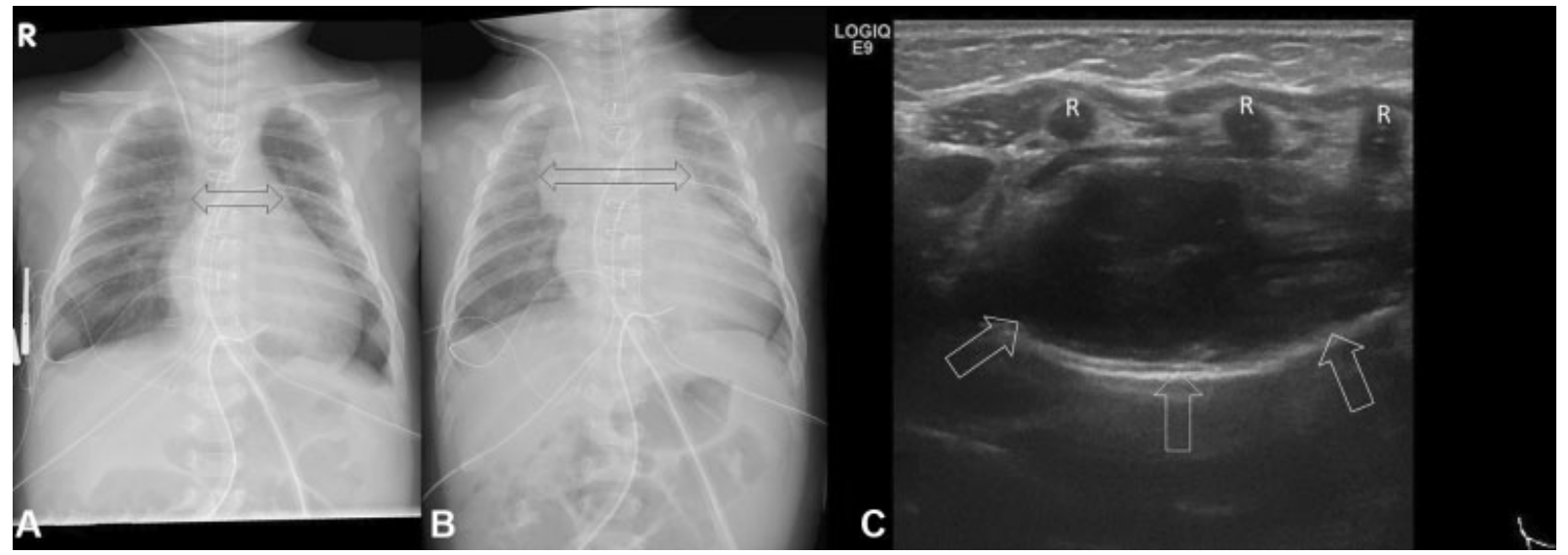

Fig. 2 Mediastinal hematoma. A 4-month-old female who underwent cardiovascular surgery for coarctation of the aorta and ventricular septal defect. The patient showed a decreased red cell blood count, and mediastinal hematoma is diagnosed. (A) Chest radiograph on the day of the operation. The width of the mediastinum is normal (double heads arrow). (B) Chest radiograph on the day after the operation. The width of the mediastinum is larger than that in - Fig. 2A (double heads arrow). Hematoma is suspected. (C) Sagittal sonogram shows fluid collection behind the retrosternal space (arrows). It has complex echogenicity. R, ribs.

is reported to be useful for diagnosing mediastinitis. ${ }^{5,12,20}$ If the circulation status is stable to undertake the ultrasound, ultrasound is used to detect the retrosternal fluid correction at the patients' bedsides. If fluid correction is detected, further examinations, such as CT, were recommended. ${ }^{9,12,19}$ Color Doppler ultrasound is useful for evaluating the intrathoracic structure and differentiating a pseudoaneurysm from the fluid correction. ${ }^{5,12}$

- Mediastinal hematoma/hemorrhage: Hematoma or bleeding at the surgical site is a critical complication during and after surgical procedures, and it is a common complication that requires reoperation. ${ }^{1}$ Hematoma results in an unstable circulation status, necessitating rapid surgical intervention. Management of hematomas may be difficult and should be based on each patient's condition. In addition to vital sign and laboratory data, image findings may be useful to diagnose this complication ( $\mathbf{- F i g . ~ 2 ) . ~}{ }^{12}$

- Surgical site infection (incisional or organ/space [mediastinitis]): surgical site infection is classified into following three types based on the depth of the infection: (1) superficial wound infection, (2) deep incisional infection, and (3) organ/space infection. Mediastinitis is classified as an organ/space infection, and it causes critical complications, has a high mortality rate, and requires adequate surgical intervention (-Figs. 3 and $\mathbf{4})^{2,9}$

\section{Sonographic Evaluation}

Ultrasound was recently reported to be useful in the evaluation of mediastinitis. ${ }^{5,12}$ Retrosternal fluid collection and

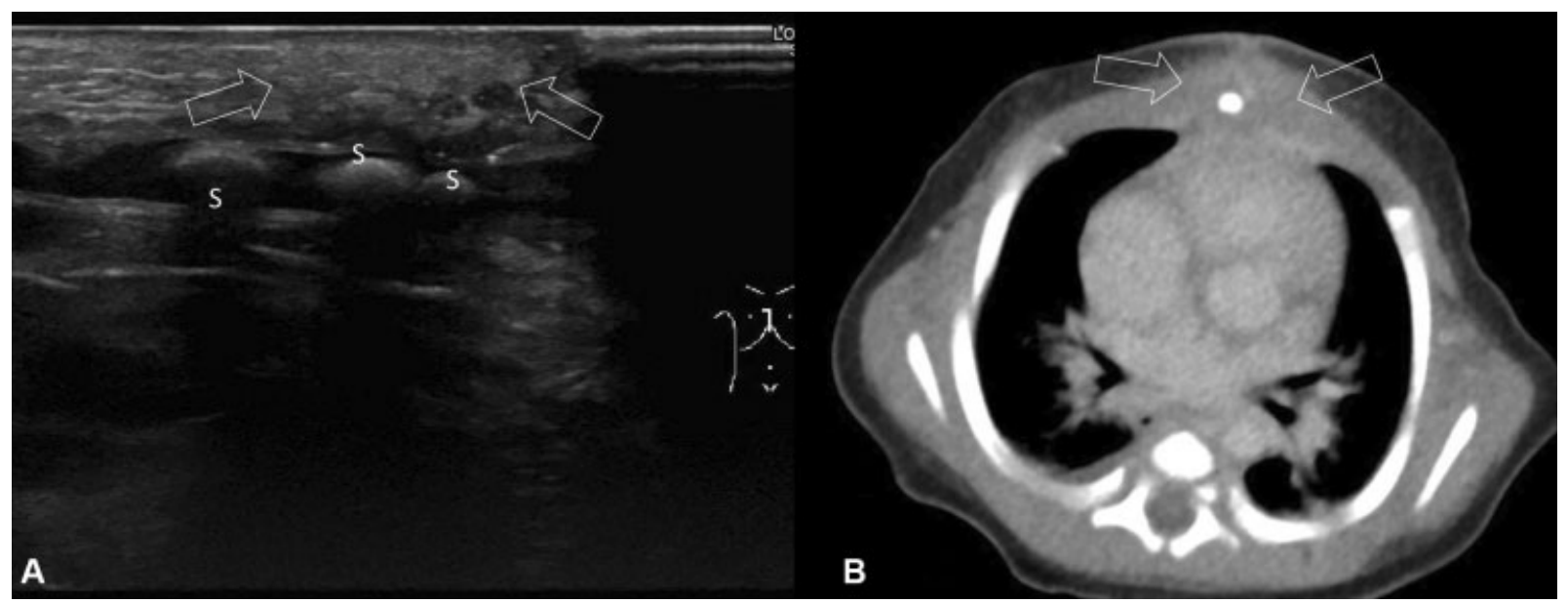

Fig. 3 Surgical site infection (deep incisional infection). Images obtained 20 days after surgery for transposition of the great arteries in a 1month-old female infant. (A) Sagittal sonogram showing a hyperechoic area in the subcutaneous fat tissue (arrows). Fluid collection behind the sternum is not detected. Presence of superficial wound infection is suspected. (B) Axial computed tomography showing absence of fluid collection behind the sternum; there is low attenuation in the subcutaneous tissue and anterior chest wall (arrows). The infection progressed to a deep incisional infection. S, separated sternal ossifications. 


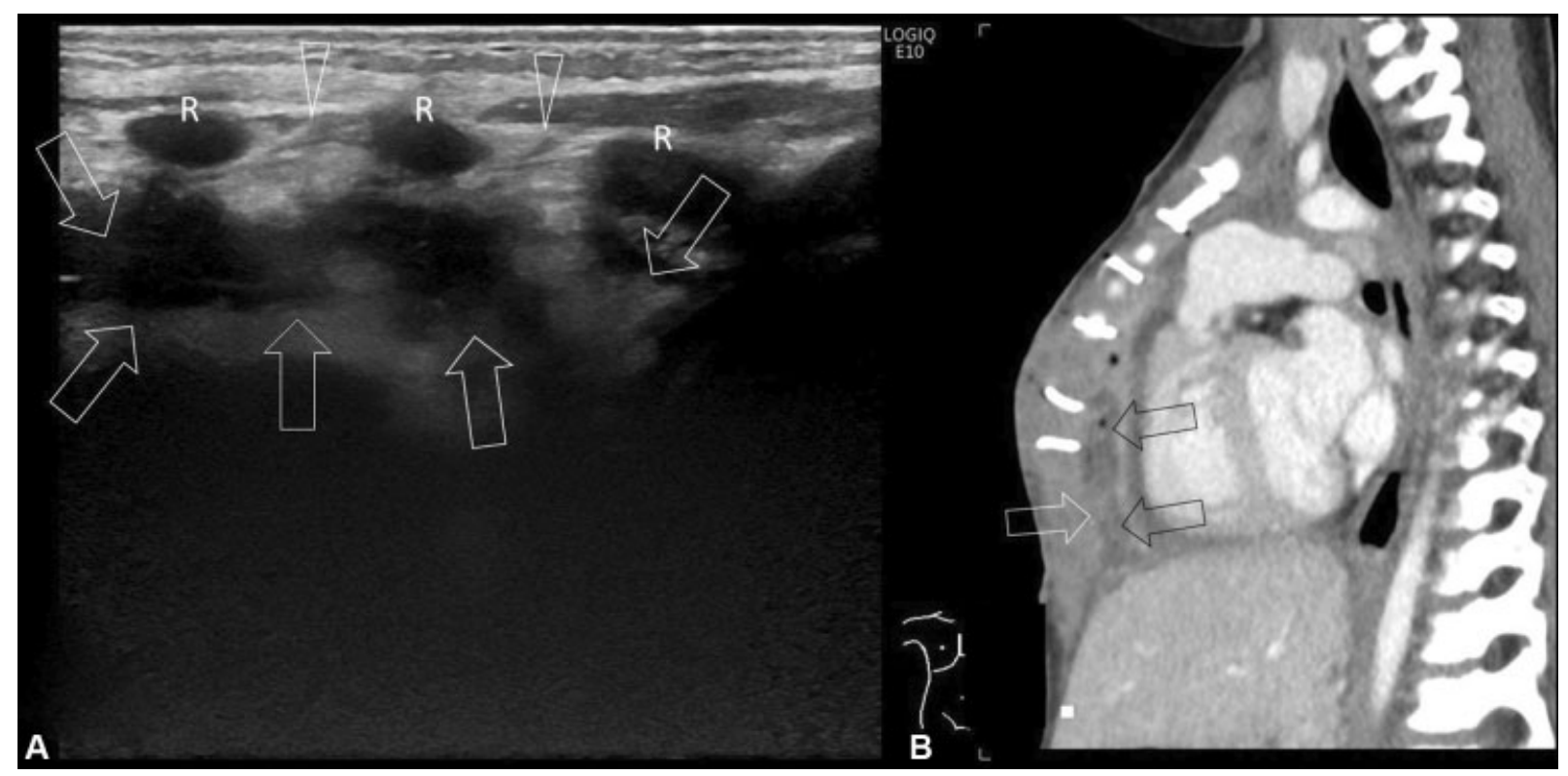

Fig. 4 Images of surgical site infection (organ/space infection; mediastinitis) that were obtained 21 days after surgery for a ventricular septal defect in a 22-month-old female child. (A) Fluid collection detected behind the sternum (arrows). Parasternal hyperechogenicity is present (arrowheads). The infection progressed to an organ/space infection (mediastinitis). (B) Sagittal computed tomography shows fluid collection with capsular enhancement (arrows) and an air bubble within the collection. Organ/space infection (mediastinitis) is diagnosed. R, the ribs.

parasternal hyperechogenicity are usually detected in cases of mediastinitis. ${ }^{12,19}$ Superficial wound infection and deep incisional infection are detected as parasternal or subcutaneous hyperechogenicity (-Fig. 3 ), and organ/space infection is detected as retrosternal fluid collection (-Fig. 4). ${ }^{5,12}$ Although these findings have high-negative predictive value for diagnosing mediastinitis, cases with hematoma may show these findings (-Fig. 2). ${ }^{9,12,19}$ In addition, Hosokawa et al reported that the two cases with mediastinitis having retrosternal simple fluid correction. ${ }^{12}$ There are various CT reports that the cases with mediastinitis had various degree of enhancement and various timing when the mediastinitis occurred. 9,17,19 Echogenicity within the retrosternal fluid correction might be varied based on the degree of inflammation, period between the examination and onset of mediastinitis, and treatment before the examination.

\section{Pleural Effusion, Thorax, and Lung Parenchyma}

Atelectasis, pneumonia, or pleural effusion associated with mechanical ventilation may occur in pediatric patients after cardiovascular surgery. ${ }^{2}$ These complications are caused by mechanical support modalities such as ventilation or extracorporeal membrane oxygenation (ECMO). ${ }^{21}$ Lung ultrasound is typically used to evaluate these complications in intensive care units. ${ }^{6,22}$

\section{Timing of Occurrence and Strategy for Diagnosis}

Hemothorax or atelectasis may occur during operation or in the intensive care unit. After ECMO, lung opacity for lung rest usually occurred within 24 hours, and may last only a few days or as long as 4 to 6 weeks depending on the patients' pulmonary condition. ${ }^{21}$ The duration between thoracic duct injury and development of chylothorax is usually 0 to 10 days. ${ }^{23}$
Pleural effusion is diagnosed by combination of clinical symptom, radiography, and ultrasound. Based on the species of pleural effusion, further recommended examination is changed. If the chylothorax suspected, lymphoscintigraphy is usually recommended. ${ }^{24-26}$

1. Pleural effusion without or with complex echogenicity

Pleural effusion is commonly observed after cardiovascular surgery. Ultrasound is a useful modality to evaluate the characteristics of this effusion (- Figs. 5 and $\mathbf{6}$ ). ${ }^{6,22}$

\section{Sonographic Evaluation}

The echogenicity within the effusion is different for the varying etiologies of pleural effusion. ${ }^{27}$ Transudative pleural effusion is anechoic (-Fig. 5), while exudative pleural effusion showed septation or nonseptation and is anechoic. ${ }^{27}$ Hemothorax occurs frequently after cardiovascular surgery. Blood in the pleural cavity shows a complex echogenicity, including hyper- to low-echoic density (-Fig. 6). ${ }^{28,29}$

\section{Chylothorax}

Chylothorax refers to the accumulation of the chyle in the pleural cavity that usually develops after disruption of the thoracic duct during intrathoracic surgery (-Fig. 7). ${ }^{23}$ Chylothorax after cardiovascular surgery is a not-so-rare complication and is related to the duration of hospitalization. ${ }^{23,30}$ Various modalities, such as lymphoscintigraphy, lymphangiography, and magnetic resonance lymphography, have been used to evaluate this condition and select appropriate treatment. ${ }^{24-26}$ However, traumatic events resulting in chylothorax are usually obvious, minor surgical trauma has also been noted to result in chylothorax. Therefore, the lymphoscintigraphy procedure is important for diagnosing chylothorax. This examination is easy compared with lymphangiography because it is performed only after 


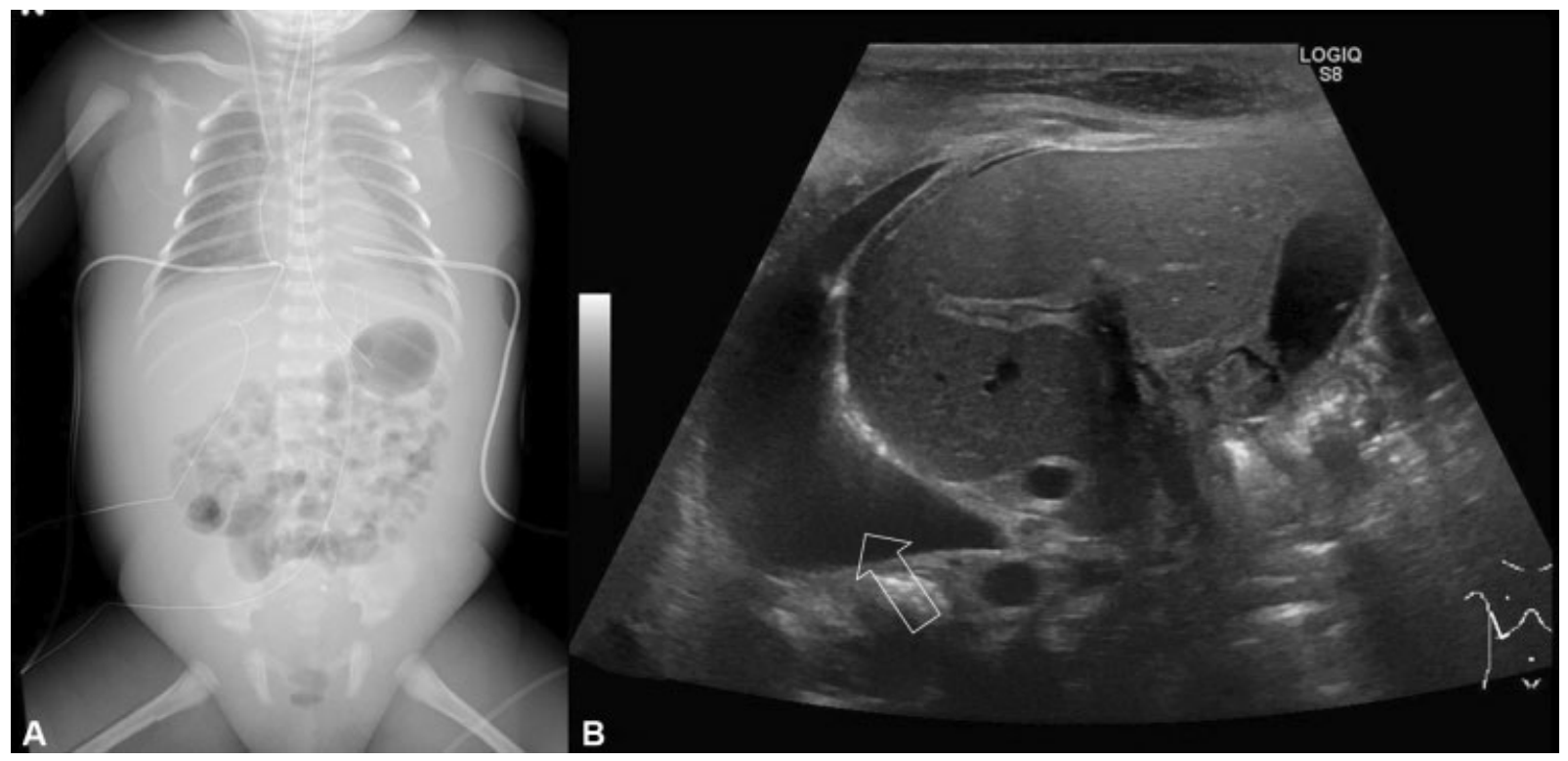

Fig. 5 Pleural effusion. A 17-day-old female patient with total anomalous pulmonary venous connection. Surgical repair was performed 7 days after birth. The effusion is characterized by serous fluid, not accumulation of chyle nor hemothorax, via the drainage tube. (A) Bilateral pleural drainages are shown in the chest radiograph. (B) Sagittal sonogram demonstrates pleural fluid at the right lung base (arrow). It does not have internal echoes or separations.

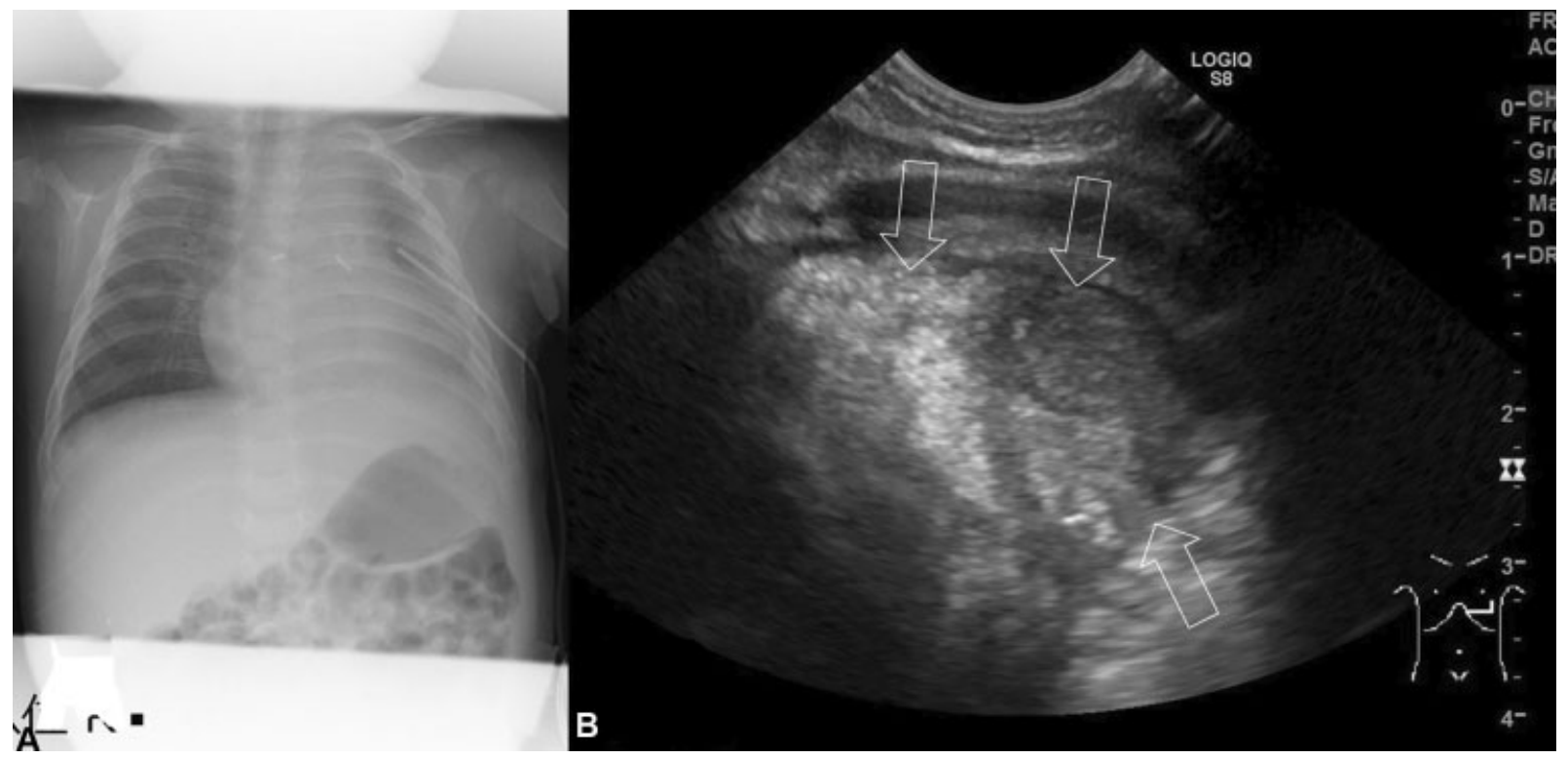

Fig. 6 Hemothorax. A 3-month-old male who underwent the Blalock-Taussig shunt. (A) Left pleural drainage is shown in the chest radiograph. (B) Axial sonogram demonstrates pleural fluid at the left lung base. It had hyper- and low-echoic density within the pleural cavity (arrows), representing hemothorax.

injection of 99 mTc-HAS-DTPA into the subcutaneous tissue of the bilateral dorsum pedis. ${ }^{31,32}$ The first treatment usually was total parenteral nutrition instead of the nutrition per mouth until chyle drainage decreases. Octreotide intravenous infusion is added in patients who do not show a response to these treatments. ${ }^{23}$ In cases showing no response to conservative treatment, including surgical ligation, lymphatic-venous anastomosis, and embolization at the leakage, point system might be performed. ${ }^{23,24,33}$

3. Pneumothorax

Pneumothorax can be demonstrated or excluded with a high degree of accuracy using ultrasound (- Figs. 8 and 9). ${ }^{6,22}$
Artifacts, such as the comet-tail sign or bands, of reverberating echoes are normally seen at the junction of the pleura and the ventilated lung. 6,22

\section{Sonographic Evaluation}

The detection of lung point, which represents the physical limit of pneumothorax, is important to diagnose the pneumothorax (-Fig. 8). ${ }^{34}$ The area with absence of lung sliding or movement of B-line, that is, comet tail-like artifact extending from pleural line to the bottom of the screen obliterating, is the area of affected pneumothorax (-Figs. 8 and 9). ${ }^{34,35}$ 


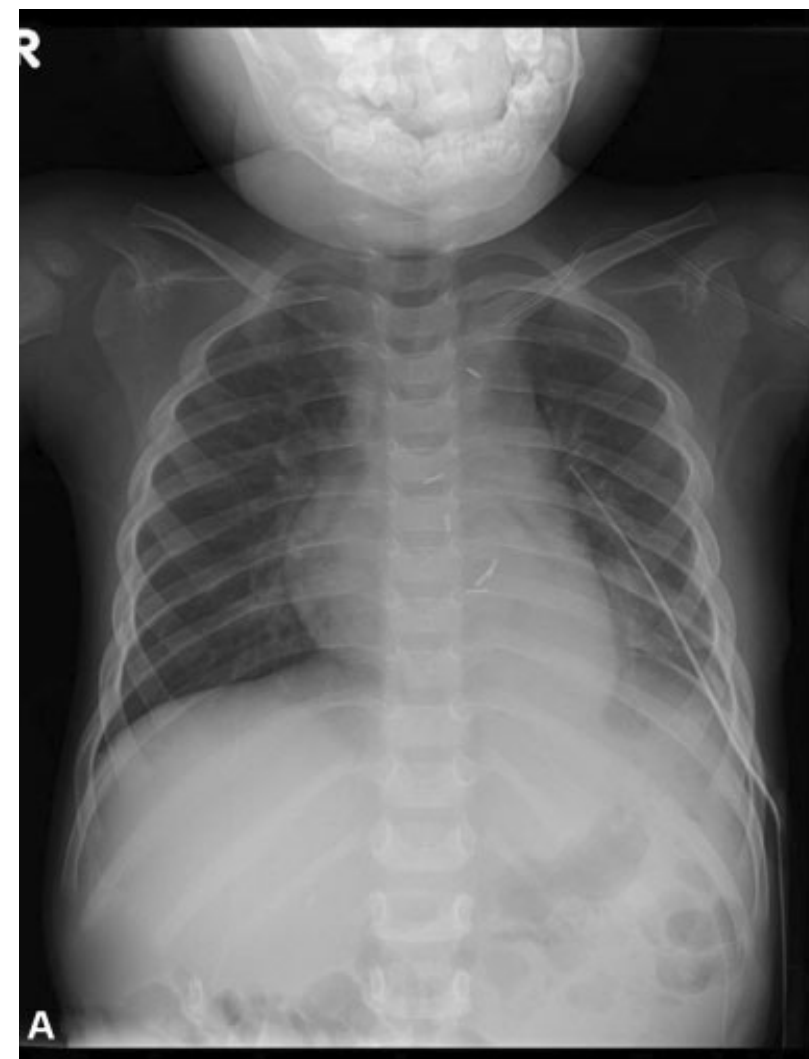

B
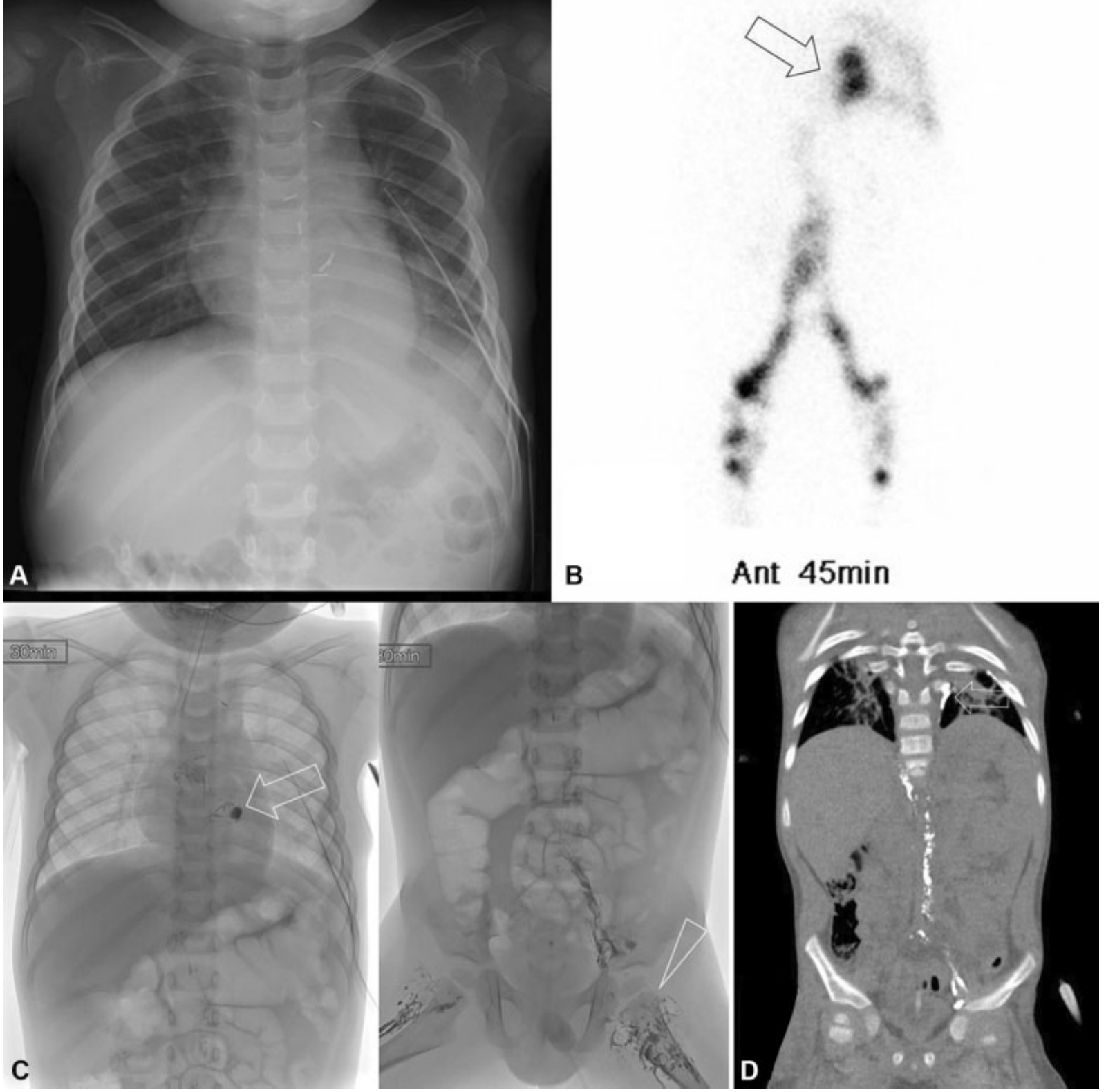

Fig. 7 Chylothorax. A 2-year-old male who underwent surgical repair for congenital heart disease. After surgical repair, accumulation of the chyle continued in the left pleural cavity. Since the patient did not respond to conservative treatment, further studies were performed. (A) Left pleural drainage is shown in the chest radiograph. (B) Radioisotope lymph scintigraphy shows abnormal tracer accumulation in the left pleural cavity (arrow). (C) Anteroposterior lymphangiogram shows lymph node as a subtle nodular stain (arrowhead). The leakage point into the left pleural cavity is revealed (arrow). (D) Coronal reconstructed computed tomography after lymphangiography shows the cisterna chyli to the leakage point (arrow).

\section{Atelectasis}

Lung atelectasis is a common finding in the intensive care unit. Aspiration, prolonged bed rest, or iatrogenic factors may result in the atelectasis. In addition, atelectasis caused by lung rest usually occurs after ECMO ( - Fig. 10). ${ }^{21}$ In patients undertaken the ECMO, the lungs show progressive opacification on radiograph. The etiology of these changes is unclear, but multifactor, such as varying degrees of widespread atelectasis and pulmonary edema, was influenced. ${ }^{21,36}$ Lung ultrasound was reported to be able to differentiate the atelectasis, lung edema, and pleural effusion. 6,11,22,34 Therefore, ultrasound may be useful morality to evaluate the lung status after ECMO.

\section{Sonographic Evaluation}

Lung aeration can be classified as well aerated, partially aerated, or completely deaerated. ${ }^{35,37}$ The well-aerated lung is seen as A-line; this is seen as parallel lines in the intercostal space that descend to the bottom of the screen (-Fig. 9). Dynamic sliding of the pleura is clearly detected in real time. The partially aerated lung is seen as B-line; this is seen as a 


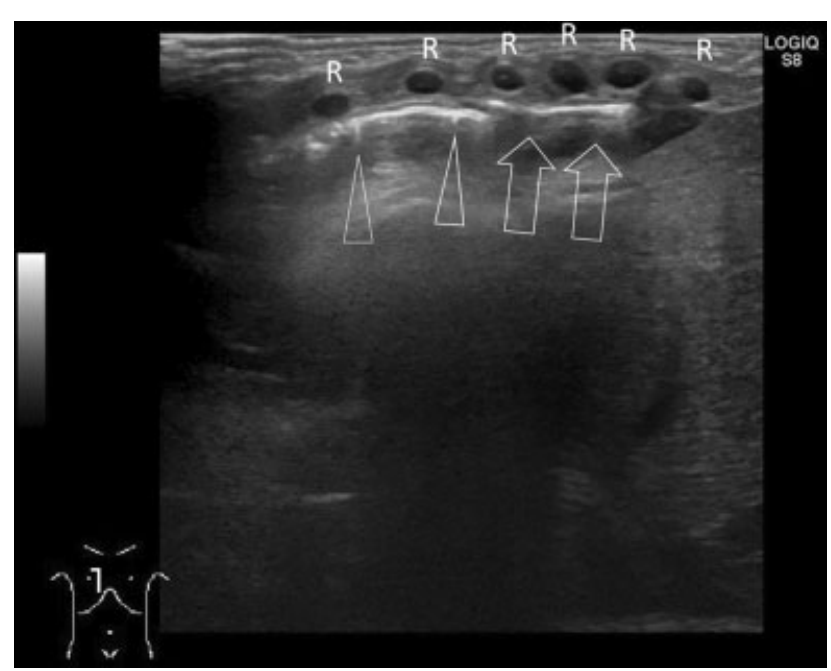

Fig. 8 Pneumothorax. Images of a 25-day-old female neonate who underwent the Blalock-Taussig shunt. Transverse sonogram shows the absence of a B-line as a comet-tail artifact (arrows), leading to a diagnosis of pneumothorax. On the left side of the pneumothorax, the presence of comettail artifacts (arrowheads) indicates the presence of lung parenchyma. $R$, ribs.

comet tail-like artifact, extending from the pleural line to the bottom of the screen ( - Fig. 8 ). Increased numbers of B-line are seen in interstitial lung disease or edema. ${ }^{37,38}$ The deaerated lung, as in lung consolidation, has a shredding appearance on the air bronchogram (-Fig. 10).

\section{Diaphragm}

\section{Phrenic Nerve Paralysis}

\section{Timing of Occurrence and Strategy for Diagnosis}

Phrenic nerve paralysis may occur during surgery. Surgical treatment, such as diaphragmatic plication, is usually performed at least 2 weeks after operation. ${ }^{39-41}$ This complication is suspected in routine radiograph and ultrasound is usually recommended to evaluate the motion of diaphragm. 3,13,22,39,42 While fluorography is also a useful morality to diagnose this complication, this procedure cannot be performed at a patient's bedside. $^{42}$

Phrenic nerve paralysis after cardiovascular surgery is associated with prolonged hospitalization ( - Fig. 11). ${ }^{39}$ Radiographic findings showing the differences on each side of the diaphragm are important to suspect the presence of phrenic nerve paralysis. ${ }^{42}$ Based on this suspicion, movement of the diaphragm is evaluated using ultrasound or fluorography. ${ }^{3,13,22,39,42}$ M-mode ultrasonography in a longitudinal view of the diaphragm is performed by positioning the probe on the posterior axillary line on one side with the transducer notch pointing 12 o'clock toward axilla. ${ }^{3}$ Paradoxical movement of the diaphragm or weak movement of the affected diaphragm is observed in cases with this complication. ${ }^{39,43}$

\section{Sonographic Evaluation}

Normal movement of the diaphragm is defined as movement toward the transducer during inspiration with an excursion of more than $4 \mathrm{~mm}$ and a difference of less than $50 \%$ between the movements of the two hemidiaphragms (-Fig. 11). Paretic movement is defined as an amplitude of less than $4 \mathrm{~mm}$ and a difference of more than $50 \%$ between the movements of the two hemidiaphragms. Paradoxical movement is defined as diaphragmatic movement away from the transducer during inspiration (-Videos 1 and 2). 3,44,45

\section{Video 1}

The position of the left diaphragm is unchanged during inspiration and expiration. The right diaphragm demonstrates normal movement. The descending aorta is located more toward the right during expiration than during inspiration. Therefore, paradoxical movement of diaphragm was diagnosed. Ao, descending aorta. Online content including video sequences viewable at: https:// www.thieme-connect.com/products/ejournals/html/ 10.1055/s-0040-1715483.

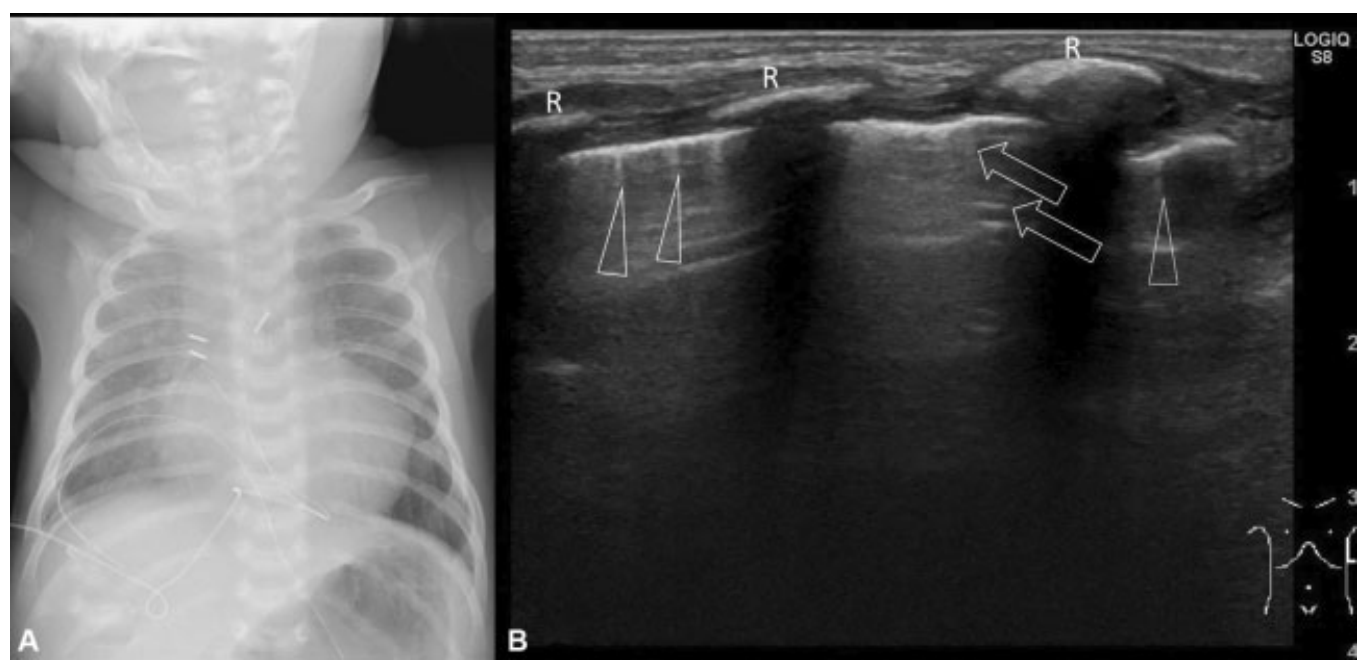

Fig. 9 Normal case without pneumothorax. Images of a 23-day-old female neonate with Blalock-Taussig shunt 1 week postoperatively. (A) On the chest radiograph, the left lung appears more radiolucent than the right lung. (B) Ultrasound shows an A-line (arrows) and a B-line as a comettail (arrowheads). Therefore, pneumothorax is not present in this case. R, ribs. 


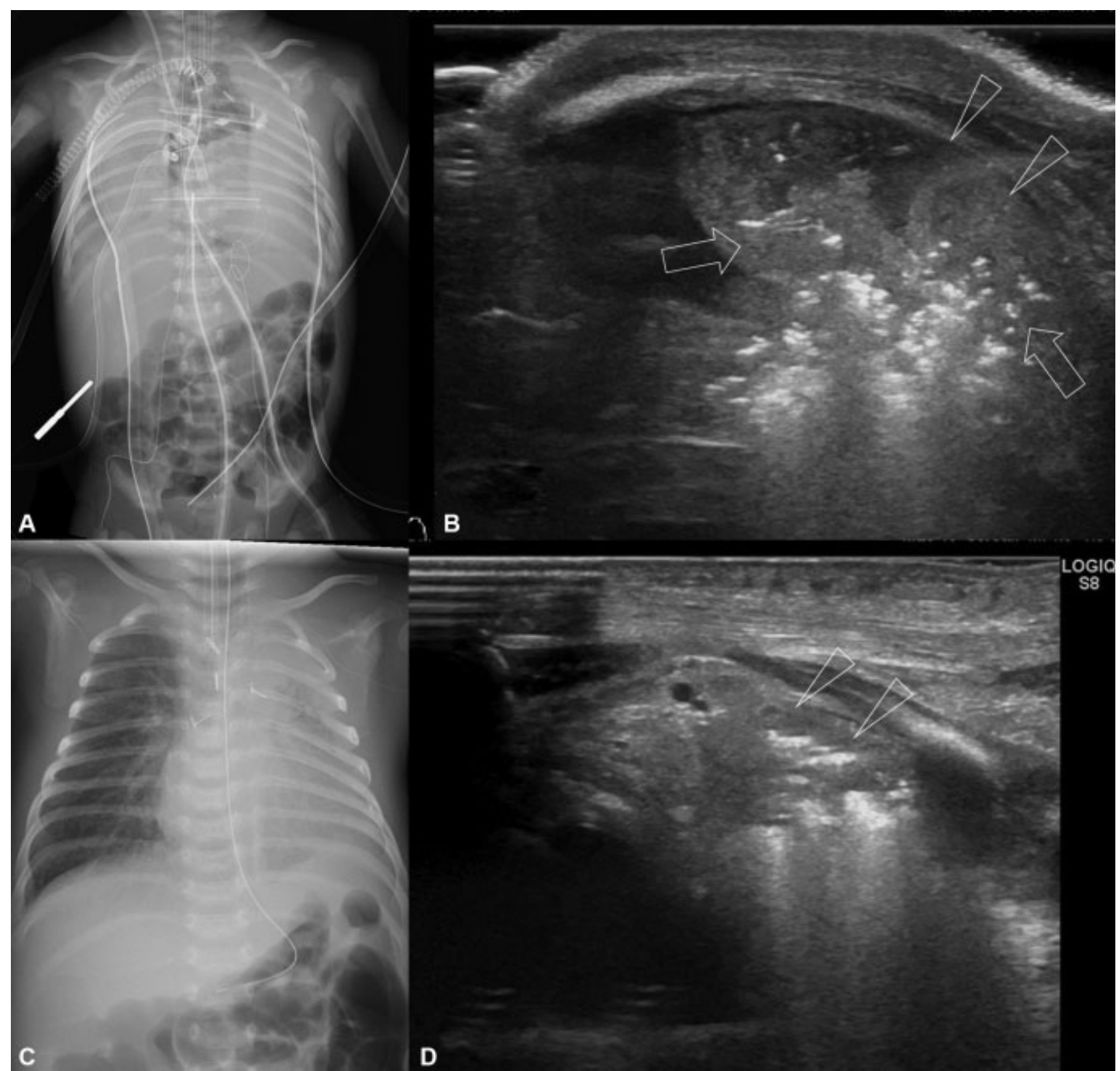

Fig. 10 Atelectasis. A 1-month-old female receiving extracorporeal membrane oxygenation after surgical repair for congenital heart disease. (A) Extracorporeal membrane oxygenation was introduced. Bilateral pleural effusion is suspected. (B) Transverse sonogram on the left base lung shows hepatization with air bronchograms in the central area of the lung (arrows) and without air bronchograms in the peripheral area of completely deaerated lung (arrowheads). (C) Chest radiograph taken after 2 weeks with lung physical therapy. (D) Transverse sonogram shows decreased area of hepatization in the left lung. In the peripheral area of the lung, air bronchogram is more clearly detected than that in B (arrowheads).

\section{Video 2}

Fluoroscopic examination of the diaphragm. The right normal hemidiaphragm descends with inspiration. The left hemidiaphragm demonstrates paradoxical upward movement with inspiration. The mediastinum is located more toward the right during expiration than during inspiration. Online content including video sequences viewable at: https://www.thieme-connect.com/ products/ejournals/html/10.1055/s-0040-1715483.

\section{Locations and Types of Complications: Intra- abdominal and Other Locations' Complications}

\section{Central nervous System}

The incidence of acute neurologic complications after cardiovascular surgery in pediatric patients is reported to be 2 to $25 \% .{ }^{46,47}$ Although the anterior fontanelle typically closes between the ages of 12 and 18 months, ultrasound via the fontanelle is useful to evaluate hemorrhage (-Table 2). ${ }^{48}$

\section{Timing of Occurrence and Strategy for Diagnosis}

Central nervous system complications are associated with hypoperfusion, cardiac arrest, or thromboembolism, or treatment such as anticoagulant therapy. ${ }^{46,47,49}$ Therefore, these complications may be encountered during cardiovascular surgery. Intracranial hemorrhage can be found 4 hours postoperatively using ultrasound.$^{50}$ However, cranial ultrasound is useful to diagnose this complication, in case with after closure of the anterior fontanelle, $\mathrm{CT}$, or magnetic resonance imaging is needed to diagnose this complication. ${ }^{51}$ Magnetic resonance imaging does not have need of radiation exposure, but it needs the relative longer time for examination compared the $\mathrm{CT}$. The values of the resistive index, peak systolic, end diastolic, and time-averaged velocities of intracranial artery are determined by using Doppler techniques, and that is useful for the diagnosis, follow-up, and management of brain damage. ${ }^{52,53}$ 


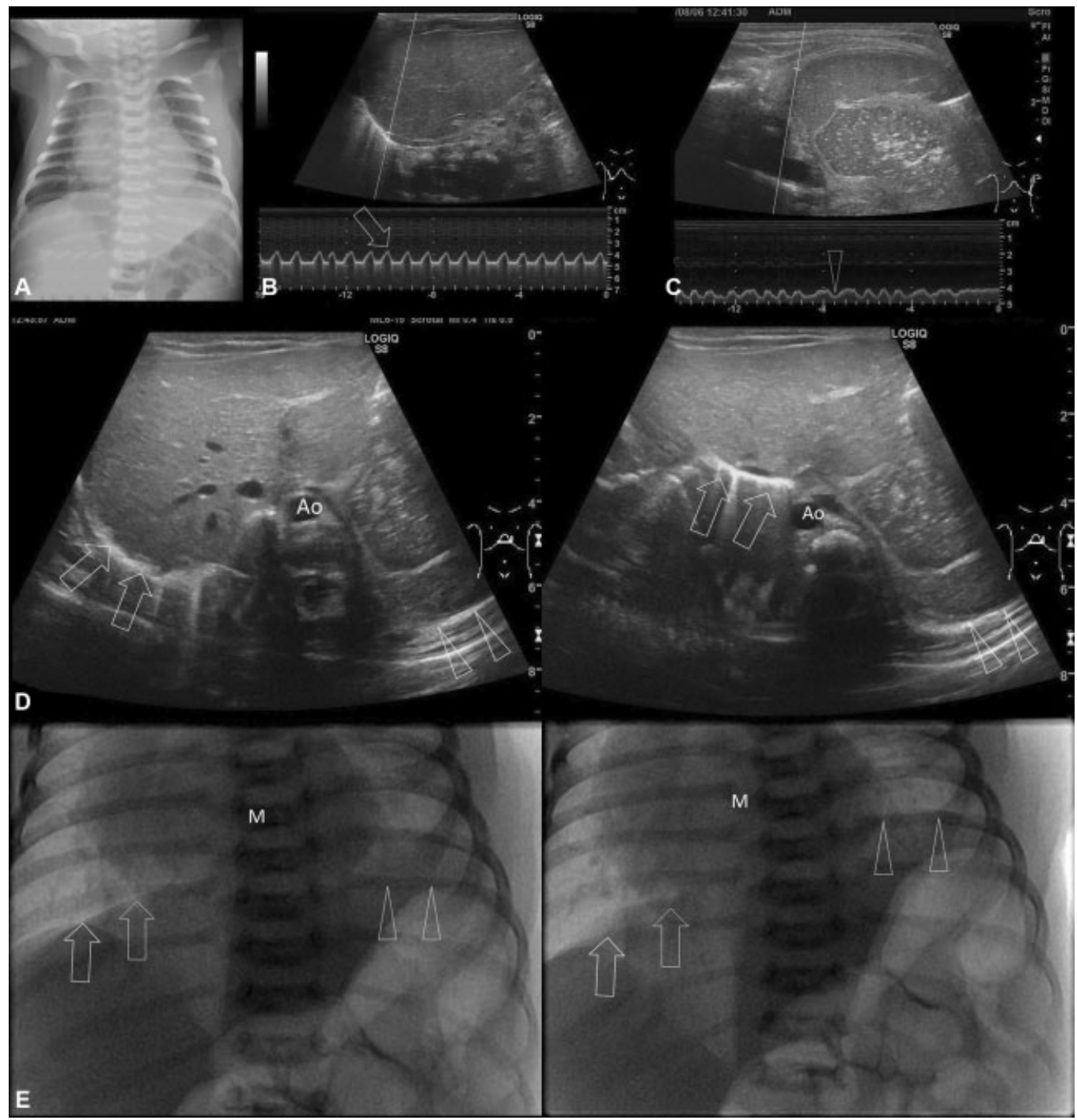

Fig. 11 Phrenic nerve paralysis. Images obtained 1 week after surgery for transposition of the great arteries in a 17-day-old female neonate. (A) Chest radiograph shows that the left diaphragm is higher than the right. (B) M-mode sonogram showing normal diaphragmatic movement during spontaneous ventilation. The movement of the right diaphragm during inspiration is toward the transducer with an excursion of more than $4 \mathrm{~mm}$ (arrow). (C) M-mode sonogram showing paradoxical diaphragmatic movement during spontaneous ventilation. The movement of the left diaphragm is away from the transducer during inspiration (arrowheads). (D) The position of the left diaphragm (arrowheads) has not changed during inspiration and expiration. The right diaphragm (arrows) shows normal movement. The descending aorta is located more toward the right during expiration than during inspiration. (E) Using fluoroscopy, mediastinum is seen toward the right during inspiration, with the left diaphragm (arrowheads) at a higher position. The right diaphragm (arrows) shows normal movement. Ao, descending aorta; M, mediastinum.

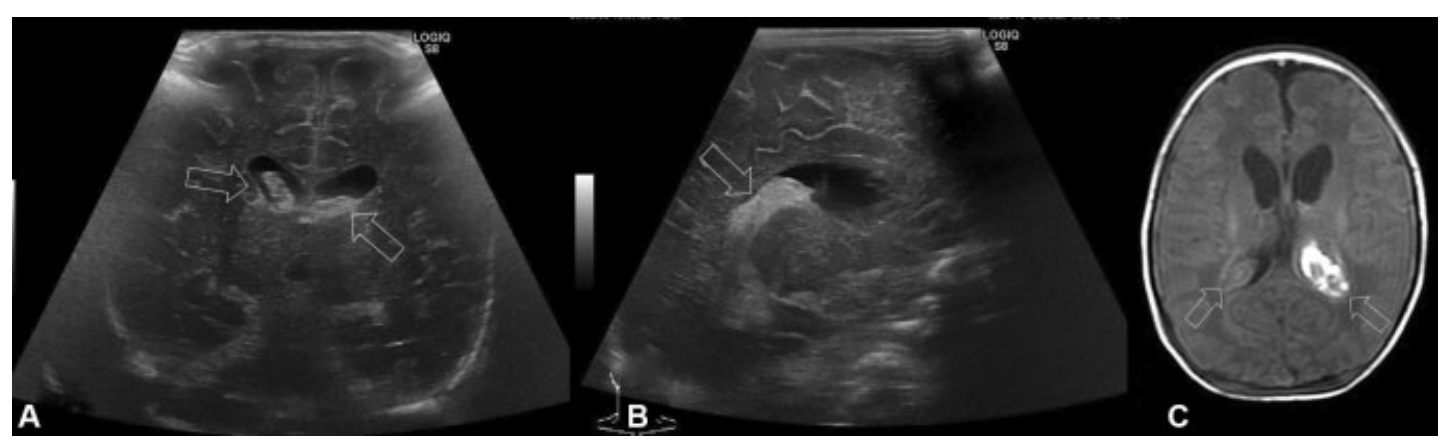

Fig. 12 Hemorrhage. An 18-day-old neonate with transposition of the great arteries. Surgical intervention with percutaneous cardiopulmonary support was performed 7 days after birth. Subsequently, intraventricular hemorrhage is detected by ultrasound examination via the anterior fontanelle. (A) Coronal sonogram shows a high-echoic mass in the right and left ventricles (arrows) without ventricular dilation. (B) Sagittal sonogram shows intraventricular hemorrhage (arrow). (C) T1-weighted magnetic resonance image shows blood with iso- to high-signal intensity in bilateral ventricles (arrows) without ventricular dilation. 


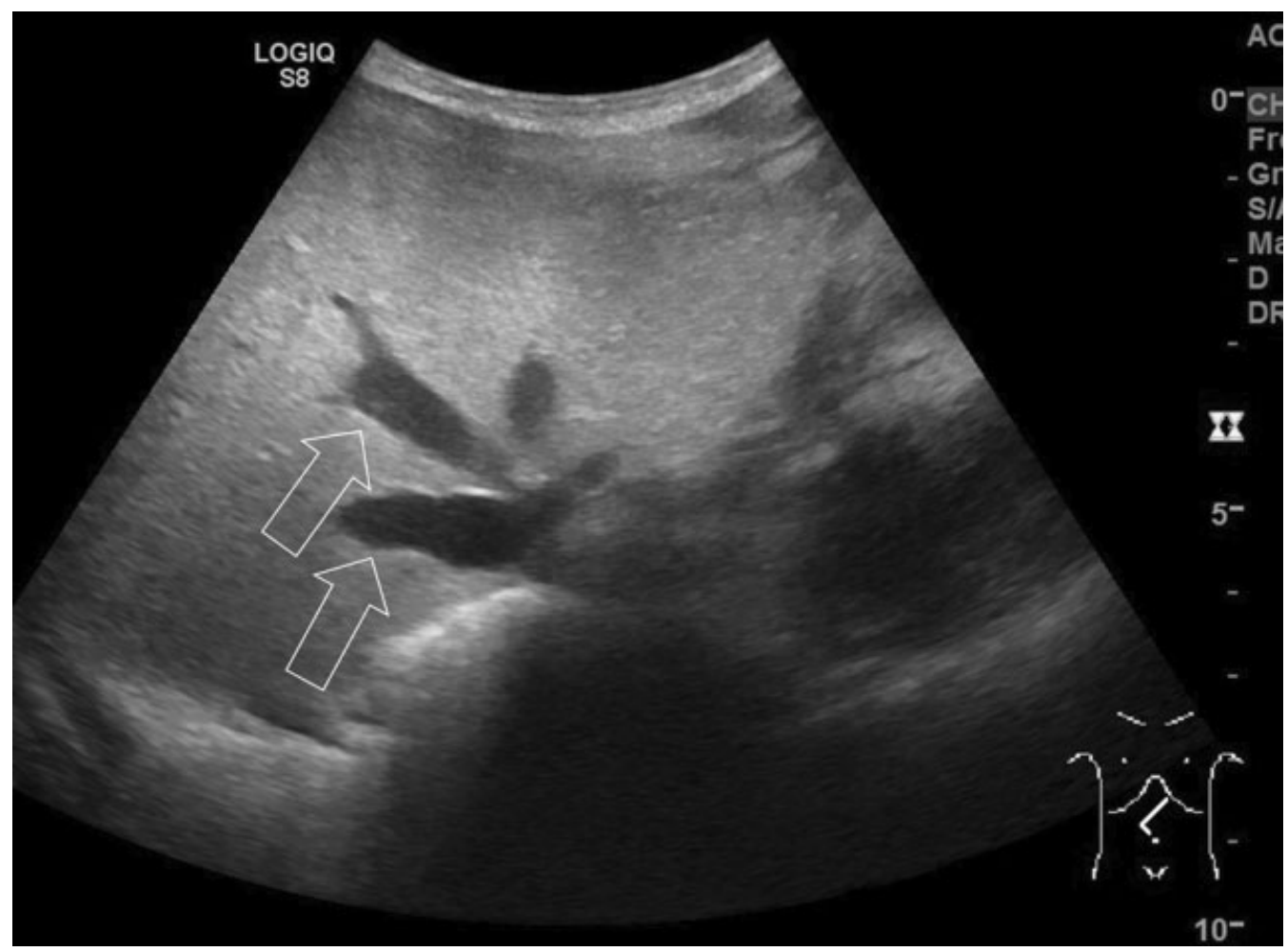

Fig. 13 Live sufficiency. A 1-year 3-month-old male with the tetralogy of Fallot: surgical repair was performed 20 days previously. Hepatic vein is dilated (arrows) due to congestion and low output circulation status.

Hemorrhage: hemorrhage is associated with anticoagulant therapy or prematurity (-Fig. 12). ${ }^{47,48}$ Ultrasound via the anterior fontanelle is useful to evaluate this complication. ${ }^{48}$ It is important to distinguish the choroid plexus hemorrhage from the normal choroid plexus, which is also echogenic. The echogenicity anterior to the caudothalamic groove represents blood as the choroid plexus finishes at the caudothalamic groove, and the choroid plexus hemorrhage is diagnosed sonographically when the affected side is enlarged, or irregular in contour as compared with the contralateral nonaffected side. ${ }^{51,54-56}$ Sequelae, such as hydrocephalus and brain atrophy, can also be evaluated using ultrasound. ${ }^{48,57}$

\section{Liver and Biliary System}

Liver dysfunction in pediatric patients with congenital heart disease is associated with congestion and low cardiac output. $^{58}$ Liver complications after the Fontan procedure are known to be chronic in nature. ${ }^{59}$ Acute liver failure after cardiovascular surgery is usually associated with low cardiac output during the operation..$^{60,61}$ In addition, fatty liver or accumulation of debris within the biliary system may be caused by using medication or total parenteral nutrition.

\section{Timing of Occurrence and Strategy for Diagnosis}

Acute liver failure or liver sufficiency is usually accompanied with low cardiac output during operation and acute renal failure. $^{60,61}$ Therefore, circulation status during the operation is important. The ultrasound should be the first method of diagnostic imaging used for inflammation of biliary system and differentiate from other liver diseases. ${ }^{62}$ The con- trast-enhanced CT or magnetic resonance imaging may be recommended to evaluate etiology of inflammation of biliary system, such as causative stone in the gallbladder or bile duct, if the etiology is not detected clearly buy ultrasound. ${ }^{62}$

- Acute liver failure (liver sufficiency): patients with acute liver failure usually show evidence of low cardiac output and acute renal failure (-Fig. 13). ${ }^{60,61}$ Acute liver failure after cardiovascular surgery may occasionally present with marked prolongation of the prothrombin time, which is associated with failure of hemostasis and hypoglycemia. ${ }^{60,61}$

- Fatty liver: fatty liver is a rare disease in pediatric patients (-Fig. 14). However, it may appear in these patients as a

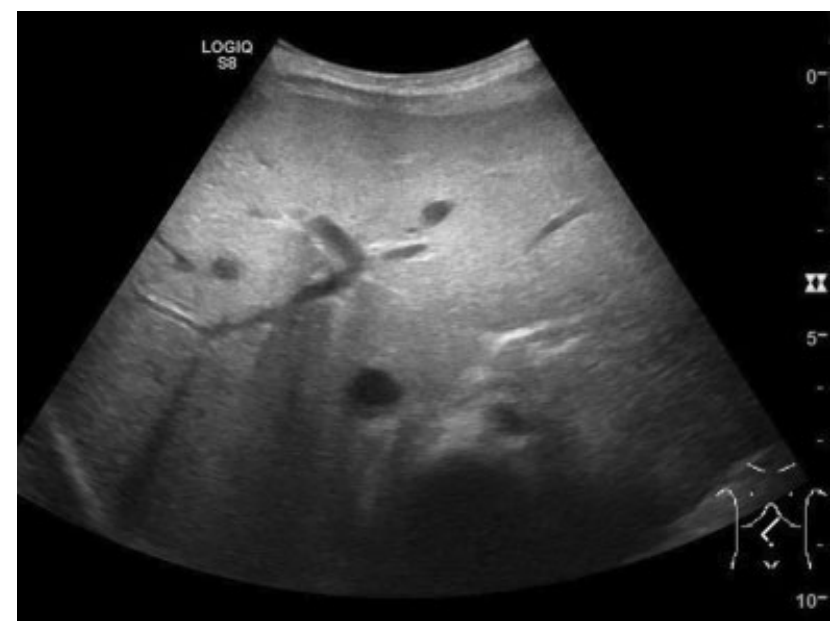

Fig. 14 Fatty liver. A 1-year 3-month-old male with the tetralogy of Fallot: surgical repair was performed 20 days previously. Liver shows hyperechogenicity rather than normal echogenicity. 


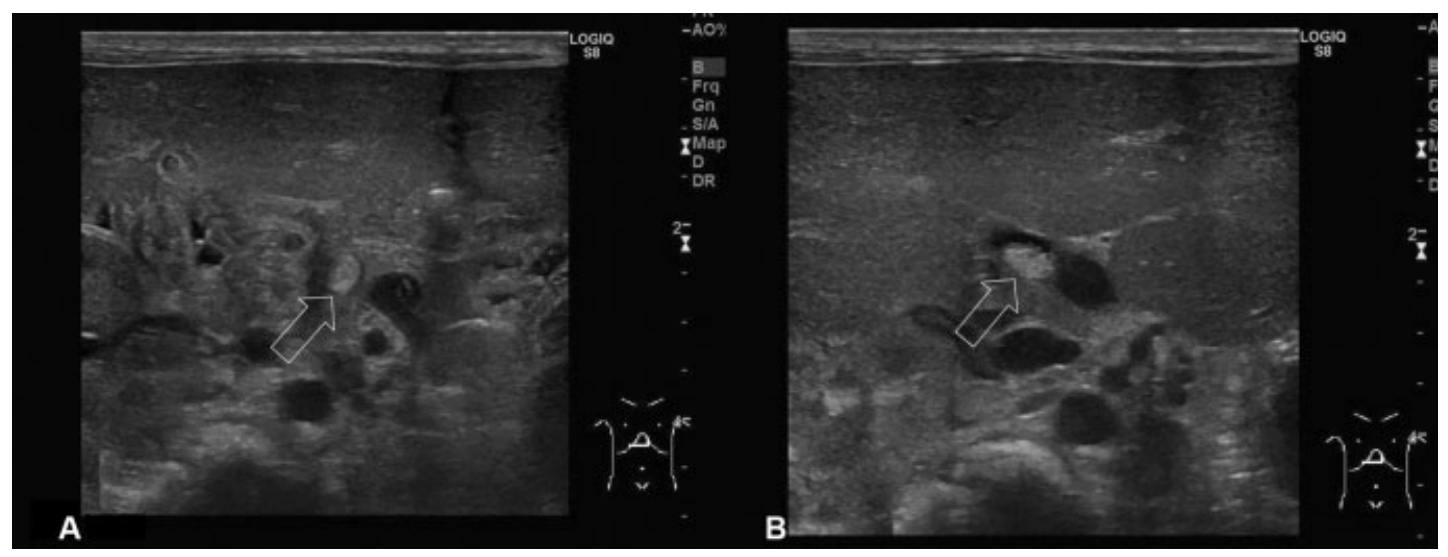

Fig. 15 Accumulation of debris within the biliary system. A 28-day-old male with the tetralogy of Fallot: surgical intervention was performed 10 days previously. (A) Transverse sonogram demonstrates debris within the common hepatic duct (arrow). (B) Transverse sonogram demonstrates debris within the common bile duct (arrow).

result of medications or total parenteral nutrition. ${ }^{63,64}$ Liver disorder in the intensive care unit is occasionally caused by fatty liver.

- Accumulation of debris within the biliary system: some drugs or total parenteral nutrition may result in the accumulation of debris within the biliary system (-Fig. 15). ${ }^{65,66}$ In some cases, this complication required appropriate treatment. ${ }^{66}$ Ultrasound is a useful modality to evaluate this condition. ${ }^{65}$

\section{Intestine}

Gastrointestinal complications after cardiovascular surgery are associated with longer hospitalization periods. ${ }^{67}$ These gastrointestinal complications include necrotizing enterocolitis, vocal cord paralysis, gastrointestinal bleeding, ileus, or enteritis. ${ }^{1,10,67,68}$ Necrotizing enterocolitis is reported to be the most common event. ${ }^{67,68}$ To prevent these complications, various enteral feeding programs are tested. ${ }^{69-71}$

\section{Timing of Occurrence and Strategy for Diagnosis}

Congenital heart disease is one of the risk factors for necrotizing enterocolitis. In addition, paradoxical hypertension may be occurred after repair of the coarctation of aorta. ${ }^{72}$ The necrotizing enterocolitis occurs even before surgery or 1 day after surgery. ${ }^{69,70,73,74}$ The diagnosis of necrotizing enterocolitis is usually performed based on the radiograph according to Bell's staging criteria. ${ }^{75-78}$ The ultrasound provides the additional information to diagnose the necrotizing enterocolitis, therefore ultrasound is recommended as the next examination. ${ }^{77}$ Paradoxical hypertension after repair of the coarctation of aorta was reported to be usually occurred 48 hours after operation. Clinical diagnosis could usually made based on the clinical sign. ${ }^{72}$

\section{Necrotizing enterocolitis}

Necrotizing enterocolitis more frequently occurs in pediatric patients with prematurity or those presenting with shock (-Figs. 16 and 17) ${ }^{68}$ Radiographic signs include a dilated intestine without peristalsis, intramural air, or portal venous gas. ${ }^{69}$ Although radiography is a useful modality to evaluate these findings, ultrasound can more easily detect the portal venous gas and other findings such as the need for an urgent surgical intervention. ${ }^{79-81}$

\section{Sonographic Evaluation}

It is important to evaluate the necessity of urgent surgical intervention in the presence of necrotizing enterocolitis. Presence or absence of intra-abdominal free air and echogenic ascites are important findings to recommend surgical intervention. ${ }^{79-83}$ There are some reports that the cases with pneumatosis intestinalis confined to the colon had better prognosis than that extended to the small intestine, therefore evaluation for location of pneumatosis intestinalis could be useful. ${ }^{79,84}$ Portal venous gas, when detected, can be traced to its origin by following the hyperechoic foci in the portal vein along its branches with real-time ultrasound (-Fig. 16C and 16D; - Videos 3-5). ${ }^{81}$

\section{Video 3}

Ultrasound image showing hyperechoic foci moving in the portal vein. Online content including video sequences viewable at: https://www.thieme-connect.com/ products/ejournals/html/10.1055/s-0040-1715483.

\section{Video 4}

Hyperechoic foci seen moving from the splenic vein to portal vein. Online content including video sequences viewable at: https://www.thieme-connect.com/ products/ejournals/html/10.1055/s-0040-1715483.

\section{Video 5}

Hyperechoic foci (arrows) seen in the inferior mesenteric vein, moving from the transverse and descending large colon. Free air and echogenic ascites are not detected and pneumatosis intestinalis is confined to the large colon. Therefore, this case was diagnosed as benign type of pneumatosis intestinalis and surgical intervention was not needed. Online content including video sequences viewable at: https://www.thieme-connect.com/ products/ejournals/html/10.1055/s-0040-1715483. 


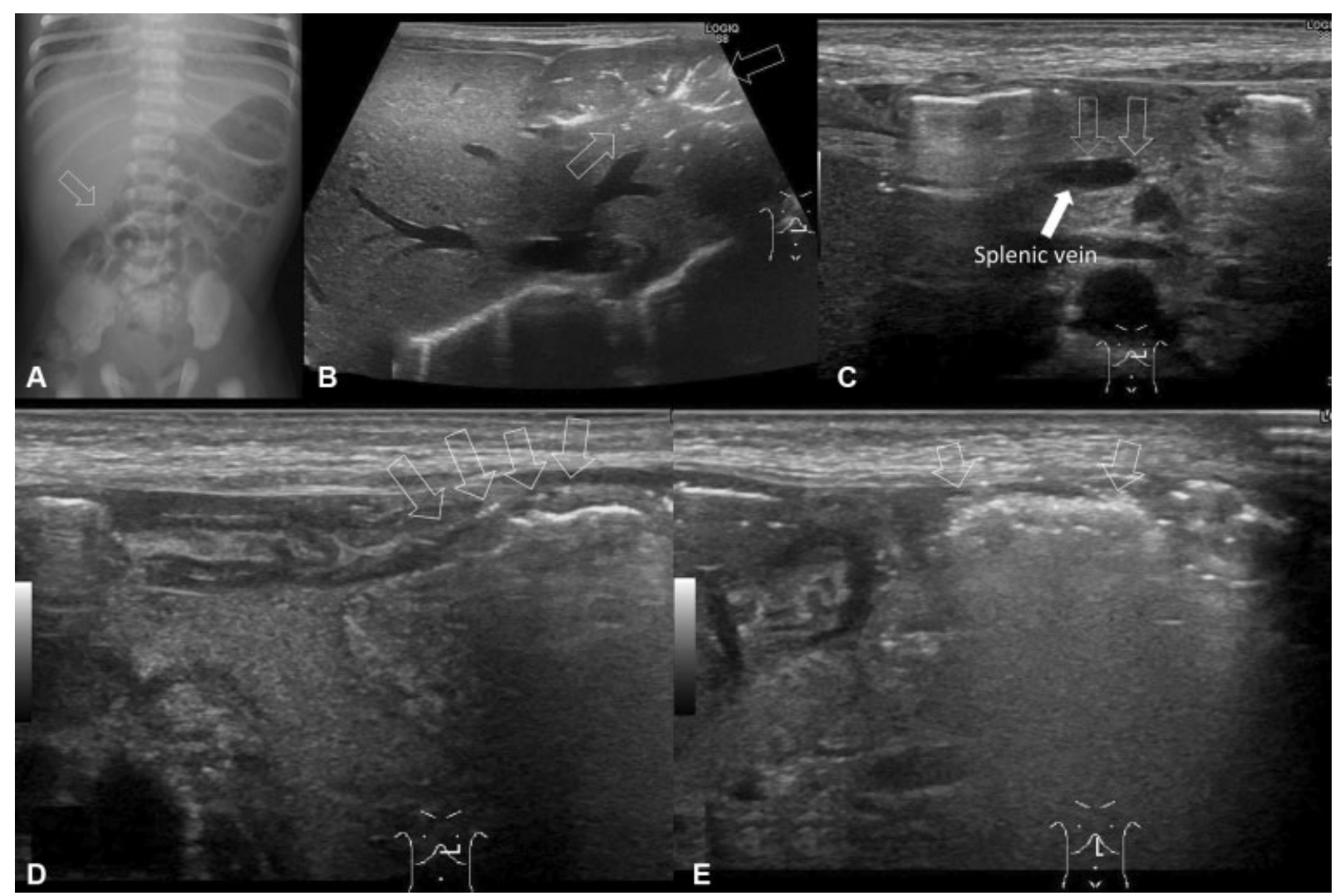

Fig. 16 Necrotizing enterocolitis. A 20-day-old male with atrioventricular septal defect who underwent surgical intervention 1 week previously. (A) Radiograph shows the absence of free air and portal venous gas. Intestinal pneumatosis located transverse colon is suspected. (B) Ultrasound image shows hyperechoic foci in the liver parenchyma in left lobe due to accumulation of gas (arrows). (C) Hyperechoic foci (arrows) are seen moving from splenic vein to portal vein. (D) Hyperechoic foci (arrows) are observed in the middle and left colic vein, moving from the transverse and descending large colon. (E) Pneumatosis intestinalis was detected at transverse colon (arrows). Free air and echogenic ascites are not detected and pneumatosis intestinalis was confined to the large colon. Therefore, this case was diagnosed as benign type of pneumatosis intestinalis and surgical intervention was not needed.

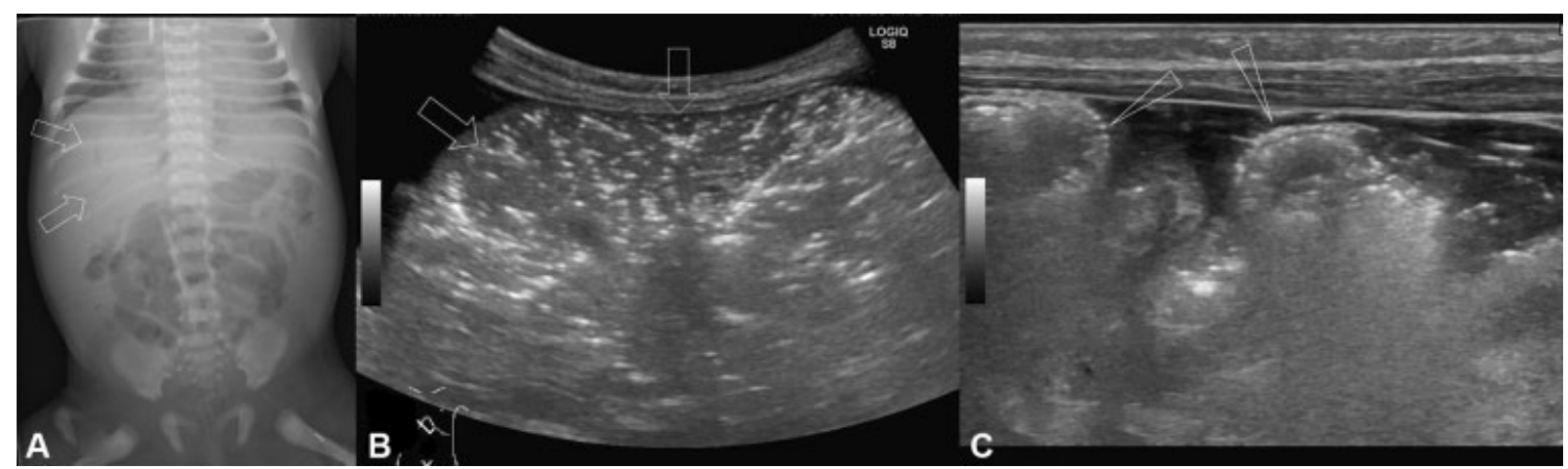

Fig. 17 Necrotizing enterocolitis. A 12-day-old female with pulmonary atresia. Pulmonary artery banding was performed. (A) Radiograph shows massive portal venous gas (arrows). (B) Ultrasound image showing many hyperechoic foci in the liver parenchyma (arrows). (C) Hyperechoic foci are observed in the wall of the small intestine (arrowheads).

2. Paradoxical hypertension results in postcoarctectomy syndrome or mesenteric arteritis

The coarctation of aorta is a little different from other congenital heart diseases. First, intra-abdominal of coarctation might be associated with occurrence of intestinal ischemia. ${ }^{85}$ Second, paradoxical hypertension might be occurred after surgical repair of coarctation of the aorta. ${ }^{72,86,87}$ The etiology is unclear but there appears to be a direct relationship to the hypertension that is observed in the postoperative period in these cases. ${ }^{72,86,87}$ This complication might be result in abdominal pain, mesenteric arteritis, or arterial aneurysm. . $2,87-90$ Recognition of this complication and early treatment for this hypertension by using antihypertensive drugs will shorten the duration of symptoms. ${ }^{72,88,89}$ Angiographic findings of this complication showed arterial segmental constriction, dilatation, or aneurysm. ${ }^{87,91}$ Ultrasound or CT was 
reported to be able to show the arterial lumen; therefore, these findings may be detected by ultrasound or CT. ${ }^{92,93}$

\section{Kidney}

Renal dysfunction, renal infectious disease, or druginduced renal dysfunction may occur in pediatric patients after cardiovascular surgery. ${ }^{1}$ Higher morbidity and mortality are associated with more severe acute kidney injuries, and this complication is also associated with a longer intensive care unit stay. ${ }^{8,94}$

\section{Timing of Occurrence and Strategy for Diagnosis}

Onset of acute kidney injury is 1 to 27 days after operation. ${ }^{94}$ In neonates, progression of acute kidney injury can occur within 48 hours after surgery ${ }^{8}$. However, acute kidney disease is diagnosed based on the clinical data such as serum creatine, not imaging modality, ultrasound might provide the information about presence or absence of urinary tract obstruction. ${ }^{95-97}$ Doppler technique is useful to evaluate the resistivity index and it is important information about renal parenchymal damage and prediction of clinical outcomes. ${ }^{97-99}$

- Acute kidney injury: the sonographic findings for acute kidney injury are not specific but ultrasound may show enlargement or high echogenicity of the renal parenchyma (-Fig. 18). ${ }^{97}$ Doppler ultrasound may be useful to predict renal function. ${ }^{8}$

- Nephrocalcinosis: nephrocalcinosis may be caused by furosemide that is usually an important medication in intensive care units (-Fig. 19). Foci with high echogenicity are easily detected by using ultrasound, and the presence or absence of hydronephrosis can be evaluated. ${ }^{100}$

- Urinary tract infection: urinary tract infection is one of the most frequent infectious foci in pediatric patients after cardiovascular surgery (-Figs. 20 and $\mathbf{2 1}$ )..$^{1,2}$ Ultrasound is reported to be useful in detecting the presence of

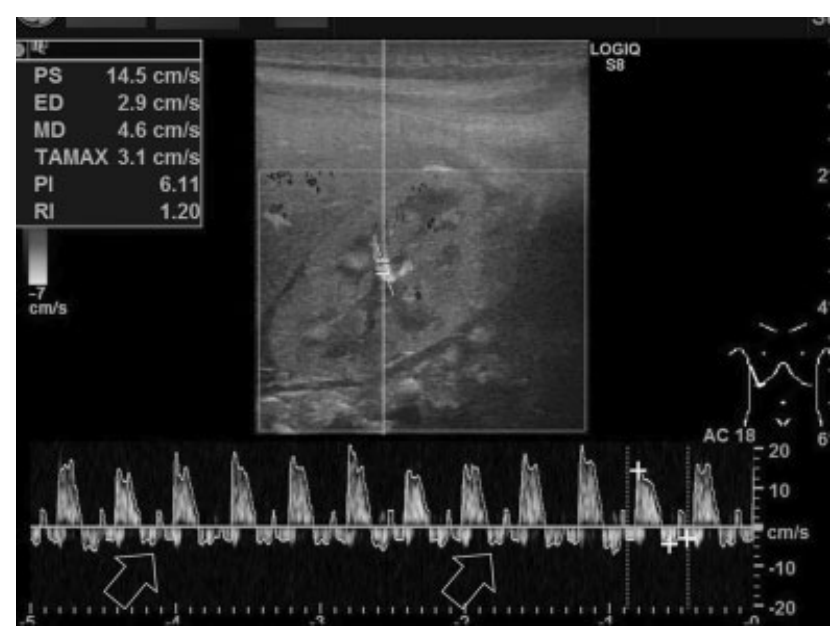

Fig. 18 Acute kidney injury. A 16-day-old female with truncus arteriosus communis. Pulmonary banding. Echogenicity of the renal cortex is slightly high. In addition, Doppler ultrasound demonstrates reversed diastolic flow (arrow), as well as a highly resistant arterial flow.

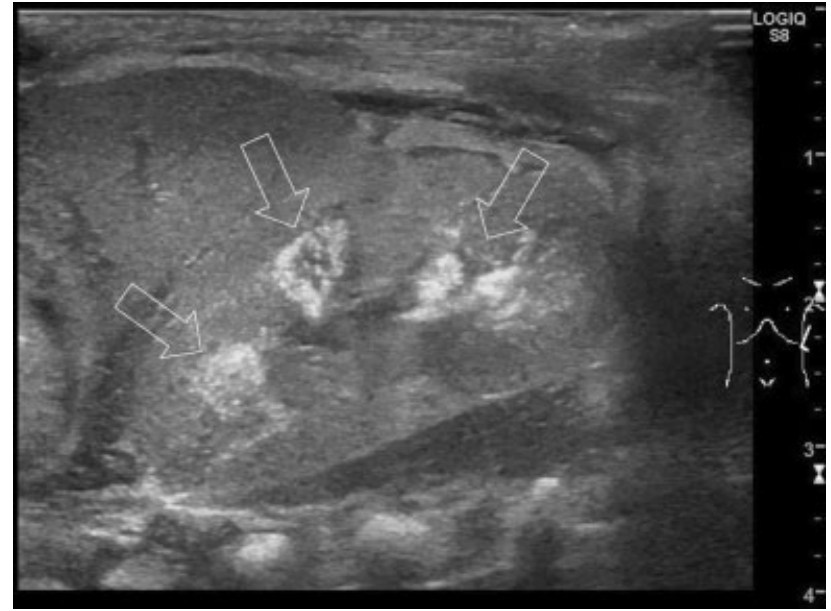

Fig. 19 Nephrocalcinosis. A 28-day-old female with total anomalous pulmonary venous return who underwent surgical repair on the birthday. Diuretic treatment was continued. Nephrocalcinosis by renal ultrasound evidenced by increased pyramidal density (arrows) associated with acoustic shadowing.

hydronephrosis and to diagnose it as pyelonephritis or acute focal bacterial nephroma. ${ }^{101}$

\section{Vascular Complications Associated with Inserted Catheter and Drainage Tube Location}

The risk of venous thrombotic events is higher in pediatric patients admitted to intensive care units. ${ }^{102}$ The presence of a central venous catheter increases this risk. ${ }^{102}$ Catheterassociated bloodstream infection is an important complication of care in children hospitalized with complex congenital heart disease. ${ }^{103}$ In addition, phlebitis and osteomyelitis caused by thrombophlebitis have been reported. ${ }^{104}$ Regardless of these potential complications, venous cannulation in intensive care units is usually unavoidable.

\section{Timing of Occurrence and Strategy of Diagnosis}

The timing of occurrence of thrombosis or phlebitis associated with catheter insertion is approximately 3 to 5 days after insertion. ${ }^{105,106}$ Physical examination is important to suspect thrombosis or phlebitis associated with catheter insertion. ${ }^{107}$ In addition, ultrasound is a useful modality to evaluate these complications. ${ }^{105,106}$ If these complications are suspected to occur at intrathoracic vein or difficult location by using ultrasound, contrast-enhanced CT could be recommended. ${ }^{108}$ Color Doppler is useful technique to detect the vessel and thrombosis. ${ }^{105,106,109}$

- Thrombosis (thrombophlebitis): venous thrombosis could be caused from an inserted catheter and patient conditions such as an underlying disease, or inadequate prophylaxis (-Figs. 22 and 23). ${ }^{102,104}$ Pulmonary embolism or thrombophlebitis caused by venous thrombosis may be critical for pediatric patients. ${ }^{110-112}$ Ultrasound is usually used to evaluate the presence of thrombosis and its complications. ${ }^{109}$

- Catheter migration: prevention of catheter migration is essential to avoid the complications associated with 


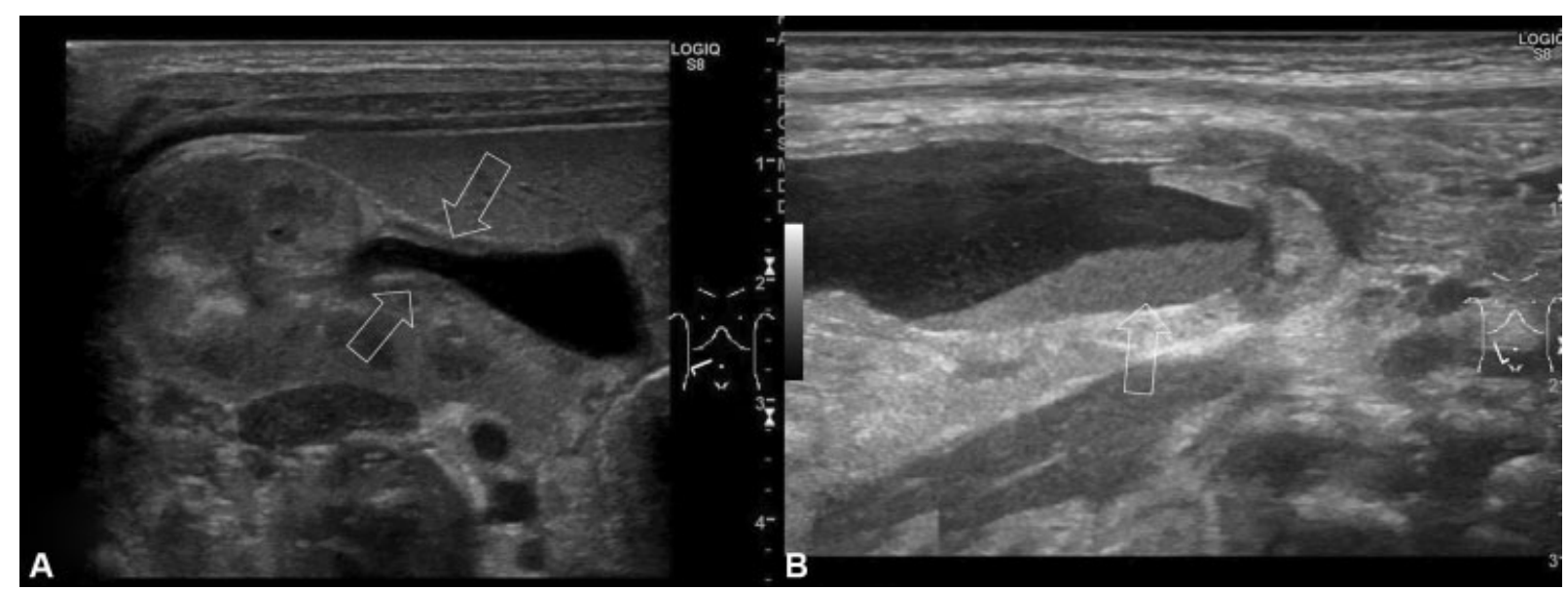

Fig. 20 Urinary tract infection. A 21-day-old female with hypoplastic left heart syndrome that underwent pulmonary artery banding 2 days previously. (A) Ultrasound demonstrates a dilated proximal ureter with a thickened ureter wall (arrows). (B) Debris appears within the dilated distal ureter (arrow).

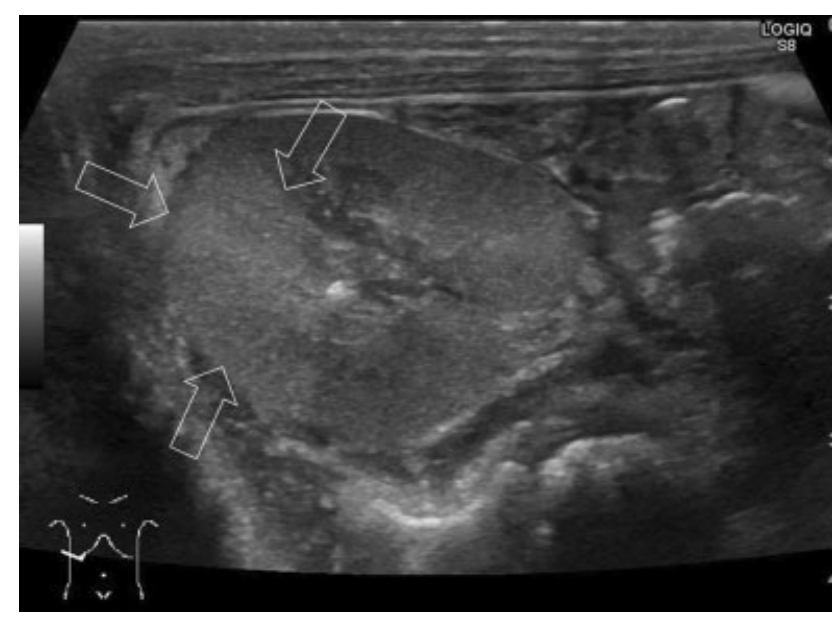

Fig. 21 Urinary tract infection. A 5-month-old male patient with atrioventricular septal defect who underwent surgical intervention 20 days previously. A transverse sonogram shows focal hyperechogenicity in the right kidney (arrows) with a focal loss of corticomedullary differentiation. Acute focal bacterial nephroma is present.

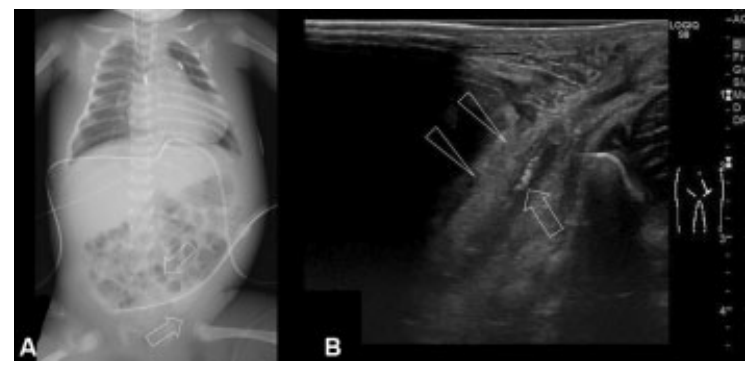

Fig. 22 Thrombophlebitis. A 1-month-old male who underwent balloon atrial septostomy. (A) Radiograph shows the PICC (arrows) is inserted in the left lower leg. (B) Oblique sonogram shows the intraluminal hyperechoic thrombus (arrows) within the left external iliac vein. Hyperechogenicity is present around the thrombus due to inflammation (arrowheads). PICC, peripheral inserted central catheter.

catheters (-Fig. 24). ${ }^{113}$ Ultrasound is a useful modality to guide cannulation and evaluate catheter migration. ${ }^{113}$

- Arrangement of the location of the drainage tube: ultrasound is useful to evaluate the location of the catheter or drainage tube (-Fig. 25). The location may be changed based on the findings obtained in ultrasound evaluations.

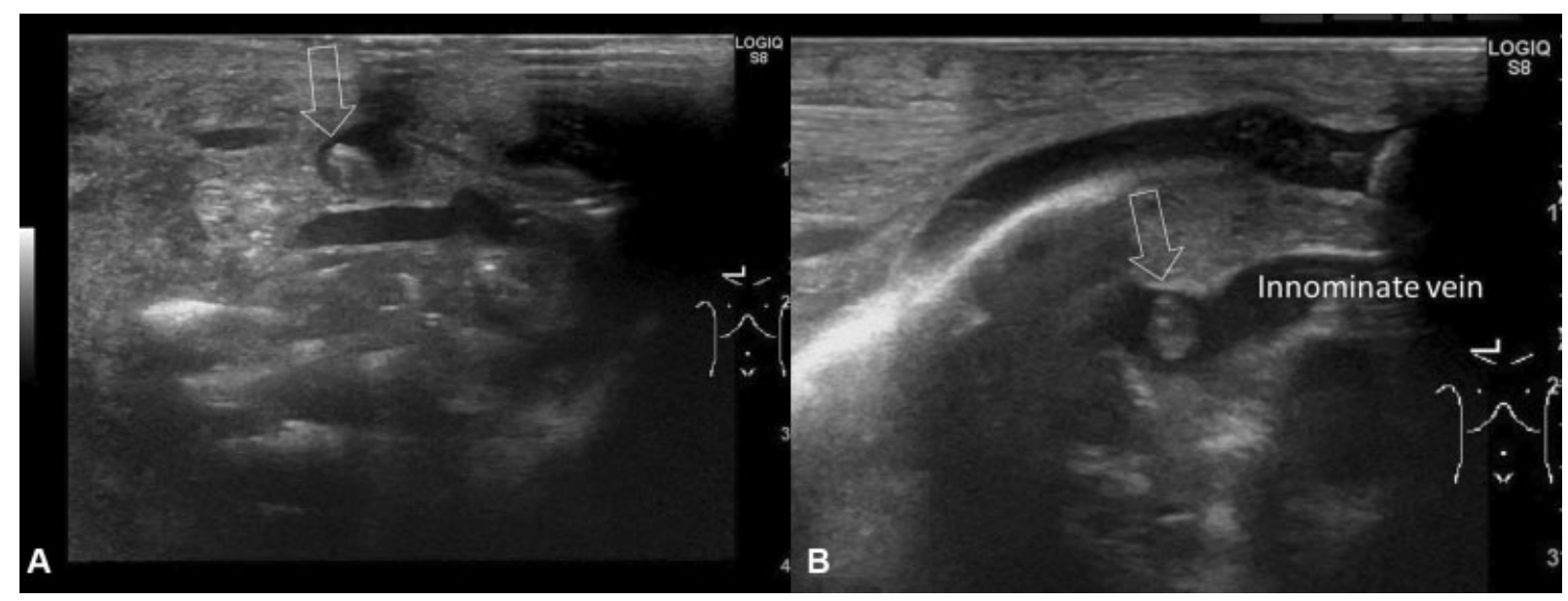

Fig. 23 Thrombosis. A 1-month-old male who underwent balloon atrial septostomy. (A) Intraluminal thrombus (arrow) is revealed within the internal carotid vein. (B) Thrombus (arrow) is located near the junction of the common carotid and innominate vein. 

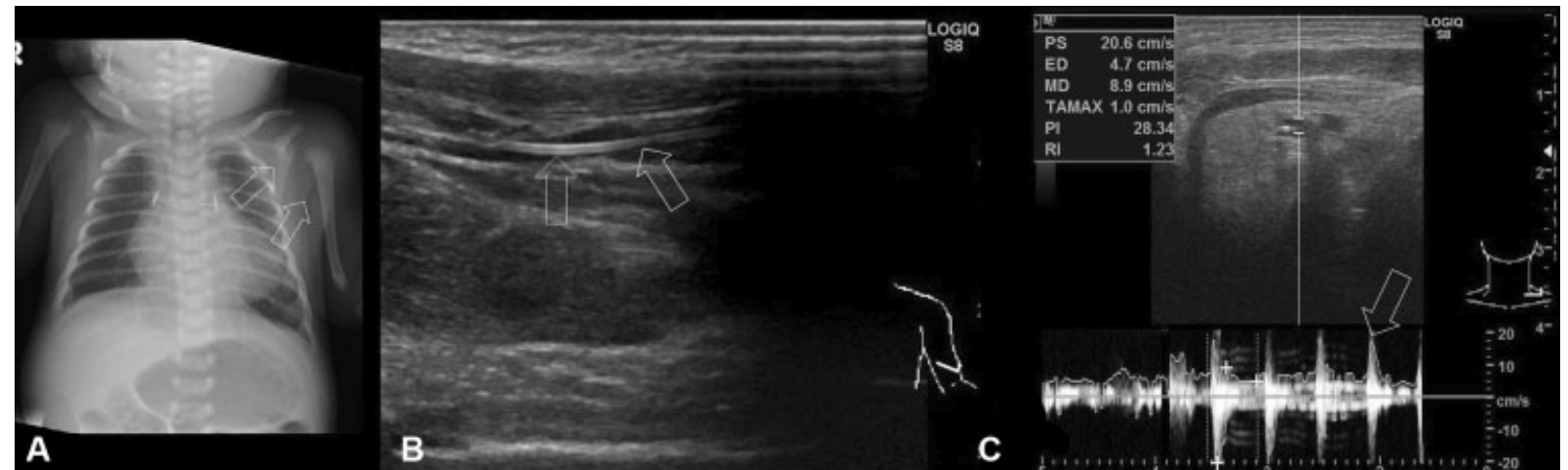

Fig. 24 Migration of catheter. A 15-day-old female who underwent pulmonary artery banding 2 weeks previously. (A) Chest radiograph shows the PICC inserted from the left upper arm (arrows). Presence or absence of migration cannot be judged from the radiograph. (B) Sagittal sonogram shows the catheter is located within the vessel (arrows). (C) Pulse-wave Doppler sonogram shows the vessel, and the catheter located within it, had arterial flow (arrow). PICC, peripheral inserted central catheter.

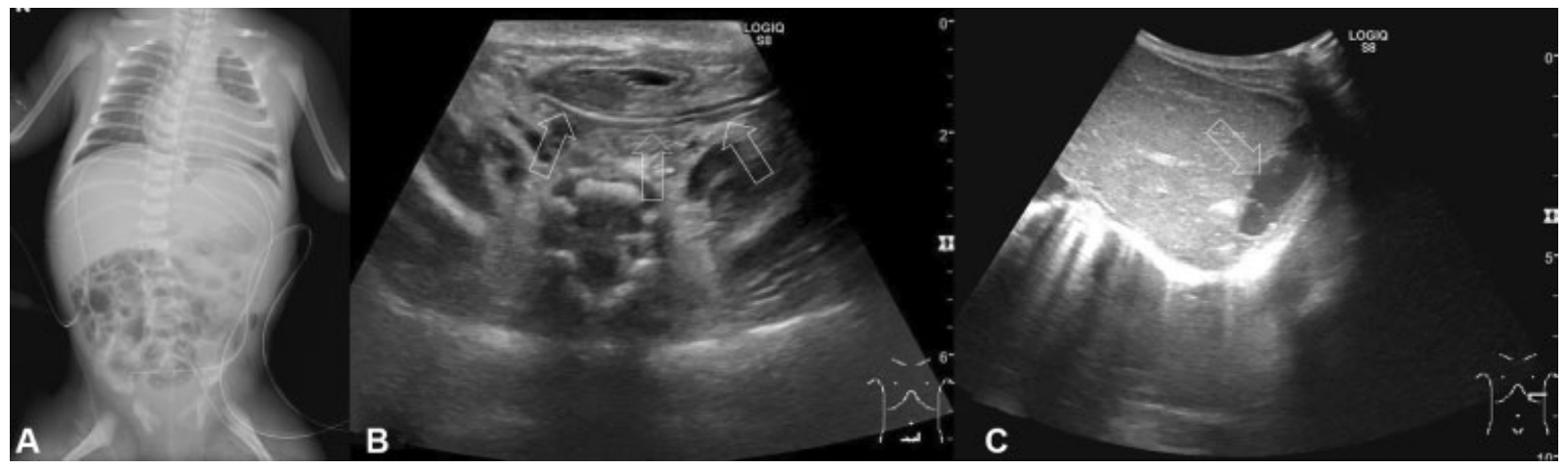

Fig. 25 Arrangement showing the location of the drainage tube. An 18-day-old male with pulmonary atresia. After pulmonary banding, necrotizing enterocolitis occurred and additional surgical intervention was needed. (A) The drainage tubes are located in the subphrenic space and pelvis. (B) There is no fluid collection around the drainage tube (arrows) located in the pelvis. Therefore, this tube was judged unnecessary. (C) Fluid collection (arrow) is detected in the left subphrenic space and it is not located around the drainage tube. The location of the drainage tube tip is arranged for drainage fluid collection.

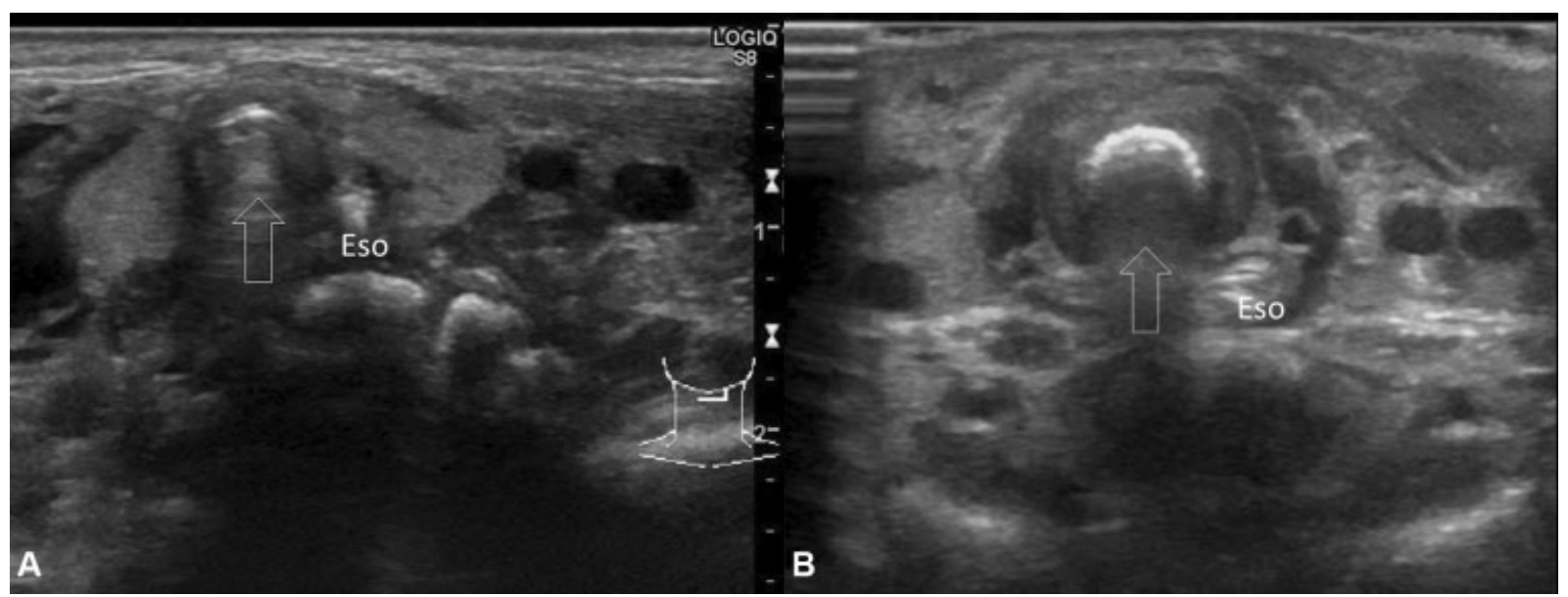

Fig. 26 Endotracheal intubation. A 1-month-old female after surgical repair for congenital heart disease. (A) Before endotracheal intubation, normal trachea (arrow) and esophagus are observed. (B) Axial sonography after endotracheal intubation showed bilaminar hyperechoic appearance appearing into the trachea (arrow). In addition, the empty esophagus can be seen to the left of the trachea. Eso, esophagus.

- Endotracheal intubation: intubation-related issues are critical for pediatric patients in intensive care units. Repeated endotracheal intubation may be sometimes needed because of various underlying diseases (-Fig. 26). Ultrasound has been reported to be useful for safe endotracheal intubation. $^{14,114}$ 


\section{Conclusion}

Various complications may occur after cardiovascular surgery. Radiography and ultrasound are important modalities to evaluate and manage these complications.

\section{Ethical Approval}

This research was performed in accordance with the tenets of the Declaration of Helsinki. This review article was approved by the ethics committee of our institution, and informed consent was waived.

\section{Conflict of Interest}

None declared.

\section{References}

1 Brown KL, Ridout D, Pagel C, et al. Incidence and risk factors for important early morbidities associated with pediatric cardiac surgery in a UK population. J Thorac Cardiovasc Surg 2019;158 (04):1185-1196.e7

2 Algra SO, Driessen MM, Schadenberg AW, et al. Bedside prediction rule for infections after pediatric cardiac surgery. Intensive Care Med 2012;38(03):474-481

3 Gil-Juanmiquel L, Gratacós M, Castilla-Fernández Y, et al. Bedside ultrasound for the diagnosis of abnormal diaphragmatic motion in children after heart surgery. Pediatr Crit Care Med 2017;18(02):159-164

4 Mangukia CV, Agarwal S, Satyarthy S, DattV, Satsangi D. Mediastinitis following pediatric cardiac surgery. J Card Surg 2014;29(01):74-82

5 Hosokawa T, Suzuki S, Tanami Y, et al. Ultrasound evaluation of complications after cardiovascular surgery in pediatric patients: A case series. Med Ultrason 2020;22(01):108-113

6 Vitale V, Ricci Z, Cogo P. Lung ultrasonography and pediatric cardiac surgery: first experience with a new tool for postoperative lung complications. Ann Thorac Surg 2014;97(04): e121-e124

7 Hosokawa T, Takahashi H, Tanami Y, et al. Diagnostic accuracy of ultrasound for the directionality of testicular rotation and the degree of spermatic cord twist in pediatric patients with testicular torsion. J Ultrasound Med 2020;39(01):119-126

8 Alabbas A, Campbell A, Skippen P, Human D, Matsell D, Mammen C. Epidemiology of cardiac surgery-associated acute kidney injury in neonates: a retrospective study. Pediatr Nephrol 2013;28(07):1127-1134

9 Hosokawa T, Yamada Y, Tanami Y, et al. Computed tomography findings of mediastinitis after cardiovascular surgery. Pediatr Int (Roma) 2020;62(02):206-213

10 Rakhit A, Nurko S, Gauvreau K, Mayer JE, Blume ED. Gastrointestinal complications after pediatric cardiac transplantation. J Heart Lung Transplant 2002;21(07):751-759

11 Bello G, Blanco P. Lung ultrasonography for assessing lung aeration in acute respiratory distress syndrome: a narrative review. J Ultrasound Med 2019;38(01):27-37

12 Hosokawa T, Tanami Y, Sato Y, Ko Y, Nomura K, Oguma E. Comparison of sonographic findings between pediatric patients with mediastinitis and without mediastinitis after cardiovascular surgery. J Med Ultrason (2001) 2020 (e-pub ahead of print). Doi: $10.1007 / \mathrm{s} 10396-020-01029-3$

13 Hosokawa T, Yamada Y, Takahashi H, et al. Postnatal ultrasound to determine the surgical strategy for congenital diaphragmatic hernia. J Ultrasound Med 2019;38(09):2347-2358

14 Mori T, Nomura O, Hagiwara Y, Inoue N. Diagnostic accuracy of a 3-point ultrasound protocol to detect esophageal or endobron- chial mainstem intubation in a pediatric emergency department. J Ultrasound Med 2019;38(11):2945-2954

15 Siegel Med. Pediatric Sonography 5th ed. Philadelphia, PA: Wolters Kluwer; 2018:156-195

16 Sachdeva R, Valente AM, Armstrong AK, et al. ACC/AHA/ASE/ HRS/ISACHD/SCAI/SCCT/SCMR/SOPE 2020 appropriate use criteria for multimodality imaging during the follow-up care of patients with congenital heart disease: a report of the American College of Cardiology Solution Set Oversight Committee and Appropriate Use Criteria Task Force, American Heart Association, American Society of Echocardiography, Heart Rhythm Society, International Society for Adult Congenital Heart Disease, Society for Cardiovascular Angiography and Interventions, Society of Cardiovascular Computed Tomography, Society for Cardiovascular Magnetic Resonance, and Society of Pediatric Echocardiography. J Am Coll Cardiol 2020;75(06):657-703

17 Yamaguchi H, Yamauchi H, Yamada T, Ariyoshi T, Aikawa H, Kato Y. Diagnostic validity of computed tomography for mediastinitis after cardiac surgery. Ann Thorac Cardiovasc Surg 2001;7(02): 94-98

18 Tortoriello TA, Friedman JD, McKenzie ED, et al. Mediastinitis after pediatric cardiac surgery: a 15-year experience at a single institution. Ann Thorac Surg 2003;76(05):1655-1660

19 Foldyna B, Mueller M, Etz CD, et al. Computed tomography improves the differentiation of infectious mediastinitis from normal postoperative changes after sternotomy in cardiac surgery. Eur Radiol 2019;29(06):2949-2957

20 Abu-Omar Y, Kocher GJ, Bosco P, et al. European Association for Cardio-Thoracic Surgery expert consensus statement on the prevention and management of mediastinitis. Eur J Cardiothorac Surg 2017;51(01):10-29

21 Thompson AF, Luan J, Al Aklabi MM, Cave DA, Ryerson LM, Noga ML. Pediatric extracorporeal membrane oxygenation (ECMO): a guide for radiologists. Pediatr Radiol 2018;48(10):1488-1502

22 Mong A, Epelman M, Darge K. Ultrasound of the pediatric chest. Pediatr Radiol 2012;42(11):1287-1297

23 Ismail SR, Kabbani MS, Najm HK, Shaath GA, Jijeh AM, Hijazi OM. Impact of chylothorax on the early post operative outcome after pediatric cardiovascular surgery. J Saudi Heart Assoc 2014;26 (02):87-92

24 Inoue M, Nakatsuka S, Yashiro H, et al. Lymphatic intervention for various types of lymphorrhea: access and treatment. Radiographics 2016;36(07):2199-2211

25 Momose M, Kawakami S, Koizumi T, et al. Lymphoscintigraphy using technetium-99m HSA-DTPA with SPECT/CT in chylothorax after childbirth. Radiat Med 2008;26(08):508-511

26 Gurevich A, Nadolski GJ, Itkin M. Novel lymphatic imaging and percutaneous treatment of chyluria. Cardiovasc Intervent Radiol 2018;41(12):1968-1971

27 Brogi E, Gargani L, Bignami E, et al. Thoracic ultrasound for pleural effusion in the intensive care unit: a narrative review from diagnosis to treatment. Crit Care 2017;21(01):325

28 Franco J, Llopis E, Galán G. Hemothorax after endobronchial ultrasound-guided transbronchial needle aspiration. J Bronchology Interv Pulmonol 2016;23(04):328-330

29 Chung MH, Hsiao CY, Nian NS, et al. The benefit of ultrasound in deciding between tube thoracostomy and observative management in hemothorax resulting from blunt chest trauma. World J Surg 2018;42(07):2054-2060

30 Ghosh RM, Griffis HM, Glatz AC, et al. Prevalence and cause of early fontan complications: does the lymphatic circulation play a role? J Am Heart Assoc 2020;9(07):e015318

31 Pui MH, Yueh TC. Lymphoscintigraphy in chyluria, chyloperitoneum and chylothorax. J Nucl Med 1998;39(07):1292-1296

32 Suga K, Kume N, Hara A, et al. Abnormal lymphatic flow demonstrated by lymphoscintigraphy in chylothorax correlation with lymphography. Clin Nucl Med 1999;24(09):716-717 
33 Kato M, Watanabe S, Iida T, Watanabe A. Flow pattern classification in lymphatic malformations by indocyanine green lymphography. Plast Reconstr Surg 2019;143(03):558e-564e

34 Raimondi F, Rodriguez Fanjul J, Aversa S, et al; Lung Ultrasound in the Crashing Infant (LUCI) Protocol Study Group. Lung ultrasound for diagnosing pneumothorax in the critically ill neonate. J Pediatr 2016;175:74-78.e1

35 Smith MJ, Hayward SA, Innes SM, Miller ASC. Point-of-care lung ultrasound in patients with COVID-19 - a narrative review. Anaesthesia 2020;75(08):1096-1104

36 Schmidt M, Pellegrino V, Combes A, Scheinkestel C, Cooper DJ, Hodgson C. Mechanical ventilation during extracorporeal membrane oxygenation. Crit Care 2014;18(01):203

37 Moore S, Gardiner E. Point of care and intensive care lung ultrasound: A reference guide for practitioners during COVID19. Radiography (Lond) 2020 (e-pub ahead of print) . Doi: 10.1016/j.radi.2020.04.005

38 Xie HQ, Zhang WW, Sun S, et al. A simplified lung ultrasound for the diagnosis of interstitial lung disease in connective tissue disease: a meta-analysis. Arthritis Res Ther 2019;21 (01):93

39 Akay TH, Ozkan S, Gultekin B, et al. Diaphragmatic paralysis after cardiac surgery in children: incidence, prognosis and surgical management. Pediatr Surg Int 2006;22(04):341-346

40 Zhao HX, D'Agostino RS, Pitlick PT, Shumway NE, Miller DC. Phrenic nerve injury complicating closed cardiovascular surgical procedures for congenital heart disease. Ann Thorac Surg 1985; 39(05):445-449

41 Zhang YB, Wang X, Li SJ, Yang KM, Sheng XD, Yan J. Postoperative diaphragmatic paralysis after cardiac surgery in children: incidence, diagnosis and surgical management. Chin Med J (Engl) 2013;126(21):4083-4087

42 de Vries TS, Koens BL, Vos A. Surgical treatment of diaphragmatic eventration caused by phrenic nerve injury in the newborn. J Pediatr Surg 1998;33(04):602-605

43 Nason LK, Walker CM, McNeeley MF, Burivong W, Fligner CL, Godwin JD. Imaging of the diaphragm: anatomy and function. Radiographics 2012;32(02):E51-E70

44 Chavhan GB, Babyn PS, Cohen RA, Langer JC. Multimodality imaging of the pediatric diaphragm: anatomy and pathologic conditions. Radiographics 2010;30(07):1797-1817

45 Epelman M, Navarro OM, Daneman A, Miller SF. M-mode sonography of diaphragmatic motion: description of technique and experience in 278 pediatric patients. Pediatr Radiol 2005;35 (07):661-667

46 Ferry PC. Neurologic sequelae of open-heart surgery in children. An 'irritating question'. Am J Dis Child 1990;144(03): 369-373

47 Menache CC, du Plessis AJ, Wessel DL, Jonas RA, Newburger JW. Current incidence of acute neurologic complications after openheart operations in children. Ann Thorac Surg 2002;73(06): 1752-1758

48 Maller VV, Cohen HL. Neonatal head ultrasound: a review and update-part 1: techniques and evaluation of the premature neonate. Ultrasound Q 2019;35(03):202-211

49 Trittenwein G, Nardi A, Pansi H, et al; Verein zur Durchführung wissenschaftlichter Forschung auf dem Gebeit der Neonatologie und Pädiatrischen Intensivmedizin. Early postoperative prediction of cerebral damage after pediatric cardiac surgery. Ann Thorac Surg 2003;76(02):576-580

50 Sigler M, Vazquez-Jimenez JF, Grabitz RG, et al. Time course of cranial ultrasound abnormalities after arterial switch operation in neonates. Ann Thorac Surg 2001;71(03):877-880

51 Svrckova P, Meshaka R, Holtrup M, et al. Imaging of cerebral complications of extracorporeal membrane oxygenation in infants with congenital heart disease - ultrasound with multimodality correlation. Pediatr Radiol 2020;50(07): 997-1009
52 Couture A, Veyrac C, Baud C, Saguintaah M, Ferran JL. Advanced cranial ultrasound: transfontanellar Doppler imaging in neonates. Eur Radiol 2001;11(12):2399-2410

53 Wong WS, Tsuruda JS, Liberman RL, Chirino A, Vogt JF, Gangitano E. Color Doppler imaging of intracranial vessels in the neonate. AJR Am J Roentgenol 1989;152(05):1065-1070

54 Parodi A, Govaert P, Horsch S, Bravo MC, Ramenghi LA; eurUS. brain group. Cranial ultrasound findings in preterm germinal matrix haemorrhage, sequelae and outcome. Pediatr Res 2020; 87(Suppl 1):13-24

55 Ortinau CM, Anadkat JS, Smyser CD, Eghtesady P. Intraventricular hemorrhage in moderate to severe congenital heart disease. Pediatr Crit Care Med 2018;19(01):56-63

56 Reeder JD, Kaude JV, Setzer ES. Choroid plexus hemorrhage in premature neonates: recognition by sonography. AJNR Am J Neuroradiol 1982;3(06):619-622

57 Maller VV, Choudhri AF, Cohen HL. Neonatal head ultrasound: a review and update-part 2: the term neonate and analysis of brain anomalies. Ultrasound Q 2019;35(03):212-223

58 Komatsu $\mathrm{H}$, Inui $\mathrm{A}$, Kishiki $\mathrm{K}$, et al. Liver disease secondary to congenital heart disease in children. Expert Rev Gastroenterol Hepatol 2019;13(07):651-666

59 Hilscher MB, Johnson JN, Cetta F, et al. Surveillance for liver complications after the Fontan procedure. Congenit Heart Dis 2017;12(02):124-132

60 Sivan Y, Nutman J, Zeevi B, Berant M, Levinsky L, Schonfeld T. Acute hepatic failure after open-heart surgery in children. Pediatr Cardiol 1987;8(02):127-130

61 Jenkins JG, Lynn AM, Wood AE, Trusler GA, Barker GA. Acute hepatic failure following cardiac operation in children. J Thorac Cardiovasc Surg 1982;84(06):865-871

62 Yokoe M, Hata J, Takada T, et al. Tokyo Guidelines 2018: diagnostic criteria and severity grading of acute cholecystitis (with videos). J Hepatobiliary Pancreat Sci 2018;25(01):41-54

63 Mitra A, Ahn J. Liver disease in patients on total parenteral nutrition. Clin Liver Dis 2017;21(04):687-695

64 Newsome PN, Cramb R, Davison SM, et al. Guidelines on the management of abnormal liver blood tests. Gut 2018;67(01): 6-19

65 Peng SS, Hsu WM, Chen HL, Mo YH. Using volume index and lateral hepatic angle to differentiate biliary atresia from TPNassociated cholestasis. J Pediatr Gastroenterol Nutr 2014;59(03): 403-408

66 de Moor RA, Egberts AC, Schröder CH. Ceftriaxone-associated nephrolithiasis and biliary pseudolithiasis. Eur J Pediatr 1999; 158(12):975-977

67 Ferguson LP, Gandiya T, Kaselas C, Sheth J, Hasan A, Gabra HO. Gastrointestinal complications associated with the surgical treatment of heart disease in children. J Pediatr Surg 2017;52 (03):414-419

68 Davies RR, Carver SW, Schmidt R, Keskeny H, Hoch J, Pizarro C. Gastrointestinal complications after stage I Norwood versus hybrid procedures. Ann Thorac Surg 2013;95(01):189-195, discussion 195-196

69 Kleinman PK, Winchester P, Brill PW. Necrotizing enterocolitis after open heart surgery employing hypothermia and cardiopulmonary bypass. AJR Am J Roentgenol 1976;127(05): 757-760

70 Luce WA, Schwartz RM, Beauseau W, et al. Necrotizing enterocolitis in neonates undergoing the hybrid approach to complex congenital heart disease. Pediatr Crit Care Med 2011;12(01):46-51

71 del Castillo SL, McCulley ME, Khemani RG, et al. Reducing the incidence of necrotizing enterocolitis in neonates with hypoplastic left heart syndrome with the introduction of an enteral feed protocol. Pediatr Crit Care Med 2010;11(03):373-377

72 Ho EC, Moss AJ. The syndrome of "mesenteric arteritis" following surgical repair of aortic coarctation. Report of nine cases and review of the literature. Pediatrics 1972;49(01):40-45 
73 O'Donovan DJ, Baetiong A, Adams K, et al. Necrotizing enterocolitis and gastrointestinal complications after indomethacin therapy and surgical ligation in premature infants with patent ductus arteriosus. J Perinatol 2003;23(04):286-290

74 Lau PE, Cruz SM, Ocampo EC, et al. Necrotizing enterocolitis in patients with congenital heart disease: A single center experience. J Pediatr Surg 2018;53(05):914-917

75 Ahle M, Ringertz HG, Rubesova E. The role of imaging in the management of necrotising enterocolitis: a multispecialist survey and a review of the literature. Eur Radiol 2018;28(09): 3621-3631

76 Juhl SM, Hansen ML, Gormsen M, Skov T, Greisen G. Staging of necrotising enterocolitis by Bell's criteria is supported by a statistical pattern analysis of clinical and radiological variables. Acta Paediatr 2019;108(05):842-848

77 Berman L, Moss RL. Necrotizing enterocolitis: an update. Semin Fetal Neonatal Med 2011;16(03):145-150

78 Panigrahi P. Necrotizing enterocolitis: a practical guide to its prevention and management. Paediatr Drugs 2006;8(03):151-165

79 Hosokawa T, Yamada Y, Tanami Y, Sato Y, Hosokawa M, Oguma E. Predictors of prognosis in children with portal venous gas detected by ultrasound. Med Ultrason 2019;21(01):30-36

80 Hosokawa T, Yamada Y, Tanami Y, Sato Y, Hosokawa M, Oguma E. Difference in detection rate of portal venous gas via computed tomography and ultrasonography in pediatric patients. Ultrasound Q 2019;35(02):181-185

81 Hosokawa T, Takahashi H, Tanami Y, Sato Y, Hosokawa M, Oguma E. Detection of intestinal pneumatosis location by following hyperechoic foci in the portal vein along its branches with real-time ultrasound. J Ultrasound Med 2019;38(02): 533-538

82 Palleri E, Kaiser S, Wester T, Arnell H, Bartocci M. Complex fluid collection on abdominal ultrasound indicates need for surgery in neonates with necrotizing enterocolitis. Eur J Pediatr Surg 2017; 27(02):161-165

83 Muchantef K, Epelman M, Darge K, Kirpalani H, Laje P, Anupindi SA. Sonographic and radiographic imaging features of the neonate with necrotizing enterocolitis: correlating findings with outcomes. Pediatr Radiol 2013;43(11):1444-1452

84 Lee KS, Hwang S, Hurtado Rúa SM, Janjigian YY, Gollub MJ. Distinguishing benign and life-threatening pneumatosis intestinalis in patients with cancer by CT imaging features. AJR Am J Roentgenol 2013;200(05):1042-1047

85 Stanley JC, Criado E, Eliason JL, Upchurch GR Jr., Berguer R, Rectenwald JE. Abdominal aortic coarctation: surgical treatment of 53 patients with a thoracoabdominal bypass, patch aortoplasty, or interposition aortoaortic graft. J Vasc Surg 2008;48 (05):1073-1082

86 Fox S, Pierce WS, Waldhausen JA. Pathogenesis of paradoxical hypertension after coarctation repair. Ann Thorac Surg 1980;29 (02):135-141

87 Shirai T, Amano J, Fujii N, Hirabayashi S, Suzuki A. Rupture of inferior phrenic artery aneurysm. An unusual complication of mesenteric arteritis due to postcoarctectomy syndrome. Chest 1994;106(04):1290-1291

88 Pirc B. [Arteritis mesenterialis - a rare complication after aortic coarctation surgery]. Acta Chir Iugosl 1980;27(Suppl 1): 527-533

89 Kounis NG. Postcoarctectomy mesenteric arteritis presenting as neonatal appendicitis. J Cardiovasc Surg (Torino) 1979;20(05): 503-505

90 Srouji MN, Trusler GA. Paradoxical hypertension and the abdominal pain syndrome following resection of coarctation of the aorta. Can Med Assoc J 1965;92(08):412-416

91 Kawauchi M, Tada Y, Asano K, Sudo K. Angiographic demonstration of mesenteric arterial changes in postcoarctectomy syndrome. Surgery 1985;98(03):602-604
92 Hosokawa T, Hosokawa M, Tanami Y, et al. Use of ultrasound findings to predict bowel ischemic changes in pediatric patients with intestinal volvulus. J Ultrasound Med 2020;39(04):683-692

93 Muorah M, Hinds R, Verma A, et al. Liver abscesses in children: a single center experience in the developed world. J Pediatr Gastroenterol Nutr 2006;42(02):201-206

94 Graziani MP, Moser M, Bozzola CM, et al. [Acute kidney injury in children after cardiac surgery: Risk factors and outcomes. A retrospective, cohort study] (in Spanish). Arch Argent Pediatr 2019;117(06):e557-e567

95 Kellum JA, Lameire N; KDIGO AKI Guideline Work Group. Diagnosis, evaluation, and management of acute kidney injury: a KDIGO summary (Part 1). Crit Care 2013;17(01):204

96 Podoll A, Walther C, Finkel K. Clinical utility of gray scale renal ultrasound in acute kidney injury. BMC Nephrol 2013;14:188

97 Kelahan LC, Desser TS, Troxell ML, Kamaya A. Ultrasound assessment of acute kidney injury. Ultrasound Q2019;35(02):173-180

98 Capotondo L, Nicolai GA, Garosi G. The role of color Doppler in acute kidney injury. Arch Ital Urol Androl 2010;82(04):275-279

99 Meola M, Petrucci I. [Ultrasound and color Doppler in nephrology. Acute kidney injury] (in Italian). G Ital Nefrol 2012;29(05): 599-615

100 Alon US, Scagliotti D, Garola RE. Nephrocalcinosis and nephrolithiasis in infants with congestive heart failure treated with furosemide. J Pediatr 1994;125(01):149-151

101 Hosokawa T, Tanami Y, Sato Y, Oguma E. Comparison of imaging findings between acute focal bacterial nephritis (acute lobar nephronia) and acute pyelonephritis: a preliminary evaluation of the sufficiency of ultrasound for the diagnosis of acute focal bacterial nephritis. Emerg Radiol 2020;27(04):405-412

102 Higgerson RA, Lawson KA, Christie LM, et al; National Association of Children's Hospitals and Related Institution's Pediatric Intensive Care Unit FOCUS Group. Incidence and risk factors associated with venous thrombotic events in pediatric intensive care unit patients. Pediatr Crit Care Med 2011;12(06):628-634

103 Prasad PA, Dominguez TE, Zaoutis TE, et al. Risk factors for catheter-associated bloodstream infections in a pediatric cardiac intensive care unit. Pediatr Infect Dis J 2010;29(09):812-815

104 Straussberg R, Harel L, Bar-Sever Z, Amir J. Radial osteomyelitis as a complication of venous cannulation. Arch Dis Child 2001;85 (05):408-410

105 Garland JS, Dunne WM Jr., Havens P, et al. Peripheral intravenous catheter complications in critically ill children: a prospective study. Pediatrics 1992;89(6 Pt 2):1145-1150

106 Schroeder AR, Axelrod DM, Silverman NH, Rubesova E, Merkel E, Roth SJ. A continuous heparin infusion does not prevent catheter-related thrombosis in infants after cardiac surgery. Pediatr Crit Care Med 2010;11(04):489-495

107 Cesarone MR, Belcaro G, Agus G, et al. Management of superficial vein thrombosis and thrombophlebitis: status and expert opinion document. Angiology 2007;58(Suppl 1):7S-14S, discussion $14 \mathrm{~S}-15 \mathrm{~S}$

108 Sonavane SK, Milner DM, Singh SP, Abdel Aal AK, Shahir KS, Chaturvedi A. Comprehensive imaging review of the superior vena cava. Radiographics 2015;35(07):1873-1892

109 Gnannt R, Waespe N, Temple M, et al. Increased risk of symptomatic upper-extremity venous thrombosis with multiple peripherally inserted central catheter insertions in pediatric patients. Pediatr Radiol 2018;48(07):1013-1020

110 Morgan RW, Stinson HR, Wolfe H, et al. Pediatric in-hospital cardiac arrest secondary to acute pulmonary embolism. Crit Care Med 2018;46(03):e229-e234

111 Khan EA, Correa AG, Baker CJ. Suppurative thrombophlebitis in children: a ten-year experience. Pediatr Infect Dis J 1997;16(01): 63-67

112 Chopra V, Anand S, Hickner A, et al. Risk of venous thromboembolism associated with peripherally inserted central catheters: a 
systematic review and meta-analysis. Lancet 2013;382 (9889):311-325

113 Motz P, Von Saint Andre Von Arnim A, Iyer RS, Chabra S, Likes M, Dighe M. Point-of-care ultrasound for peripherally inserted central catheter monitoring: a pilot study. J Perinat Med 2019; 47(09):991-996

114 Arya R, Schrift D, Choe C, Al-Jaghbeer M. Real-time tracheal ultrasound for the confirmation of endotracheal intubations in the intensive care unit: an observational study. J Ultrasound Med 2019;38(02):491-497

115 Sabzi F, Faraji R, Kazeminasab M. Minimal invasive technique in atrial septal defect surgery. Cardiol Res 2018;9(02):90-93

116 Myers PO, Mokashi SA, Horgan E, et al. Outcomes after mechanical aortic valve replacement in children and young adults with congenital heart disease. J Thorac Cardiovasc Surg 2019;157(01): 329-340

117 Baumann Kreuziger L, Karkouti K, Tweddell J, Massicotte MP. Antithrombotic therapy management of adult and pediatric cardiac surgery patients. J Thromb Haemost 2018;16(11):2133-2146

118 Nateghian A, Taylor G, Robinson JL. Risk factors for surgical site infections following open-heart surgery in a Canadian pediatric population. Am J Infect Control 2004;32(07):397-401

119 Allpress AL, Rosenthal GL, Goodrich KM, Lupinetti FM, Zerr DM. Risk factors for surgical site infections after pediatric cardiovascular surgery. Pediatr Infect Dis J 2004;23(03):231-234

120 Edwards MS, Baker CJ. Median sternotomy wound infections in children. Pediatr Infect Dis 1983;2(02):105-109

121 Nelson-McMillan K, Hornik CP, He X, et al. Delayed sternal closure in infant heart surgery-the importance of where and when: an analysis of the STS congenital heart surgery database. Ann Thorac Surg 2016;102(05):1565-1572

122 Al-Sehly AA, Robinson JL, Lee BE, et al. Pediatric poststernotomy mediastinitis. Ann Thorac Surg 2005;80(06):2314-2320

123 Ohye RG, Maniker RB, Graves HL, Devaney EJ, Bove EL. Primary closure for postoperative mediastinitis in children. J Thorac Cardiovasc Surg 2004;128(03):480-486

124 Mehta PA, Cunningham CK, Colella CB, Alferis G, Weiner LB. Risk factors for sternal wound and other infections in pediatric cardiac surgery patients. Pediatr Infect Dis J 2000;19(10): 1000-1004

125 Long CB, Shah SS, Lautenbach E, et al. Postoperative mediastinitis in children: epidemiology, microbiology and risk factors for gram-negative pathogens. Pediatr Infect Dis J 2005;24(04): 315-319
126 Anslot C, Hulin S, Durandy Y. Postoperative mediastinitis in children: improvement of simple primary closed drainage. Ann Thorac Surg 2007;84(02):423-428

127 Fleck T, Simon P, Burda G, Wolner E, Wollenek G. Vacuum assisted closure therapy for the treatment of sternal wound infections in neonates and small infants. Interact Cardiovasc Thorac Surg 2006;5(03):285-288

128 Tönz M, von Segesser LK, Mihaljevic T, Arbenz U, Stauffer UG, Turina MI. Clinical implications of phrenic nerve injury after pediatric cardiac surgery. J Pediatr Surg 1996;31(09): 1265-1267

129 Greene CL, Mainwaring RD, Sidell D, Yarlagadda VV, Patrick WL, Hanley FL. Impact of phrenic nerve palsy and need for diaphragm plication following surgery for pulmonary atresia with ventricular septal defect and major aortopulmonary collaterals. Semin Thorac Cardiovasc Surg 2018;30(03):318-324

130 Paret G, Gilad E, Jonas A, Meyers JJ, Barzilay Z. Acute acalculous cholecystitis in an infant after cardiac surgery. J Pediatr Surg 1994;29(12):1580-1581

131 Carpenito KR, Prusinski R, Kirchner K, et al. Results of a feeding protocol in patients undergoing the hybrid procedure. Pediatr Cardiol 2016;37(05):852-859

132 Elella RA, Habib E, Mokrusova P, et al. Incidence and outcome of acute kidney injury by the pRIFLE criteria for children receiving extracorporeal membrane oxygenation after heart surgery. Ann Saudi Med 2017;37(03):201-206

133 Grieshaber P, Möller S, Arneth B, et al. Predicting cardiac surgeryassociated acute kidney injury using a combination of clinical risk scores and urinary biomarkers. Thorac Cardiovasc Surg 2019

134 Greenberg JH, Parsons M, Zappitelli M, et al. Cardiac biomarkers for risk stratification of acute kidney injury after pediatric cardiac surgery. Ann Thorac Surg 2020 (e-pub ahead of print) . Doi: 10.1016/j.athoracsur.2020.03.010

135 Aydin SI, Seiden HS, Blaufox AD, et al. Acute kidney injury after surgery for congenital heart disease. Ann Thorac Surg 2012;94 (05):1589-1595

136 Atchison CM, Amankwah E, Wilhelm J, et al. Risk factors for hospital-associated venous thromboembolism in critically ill children following cardiothoracic surgery or therapeutic cardiac catheterisation. Cardiol Young 2018;28(02):234-242

137 Parikh CR, Devarajan P, Zappitelli M, et al. Postoperative biomarkers predict acute kidney injury and poor outcomes after pediatric cardiac surgery. J Am Soc Nephrol 2011;22(09): $1737-1747$ 